\title{
Highly efficient ligands for DHFR from Cryptosporidium hominis and Toxoplasma gondii inspired by structural analysis
}

Phillip Pelphrey, Veljko M. Popov, Tammy M. Joska, Jennifer M. Beierlein, Erin S. D. Bolstad, Yale A. Fillingham, Dennis L. Wright and Amy C. Anderson

Supporting Information

S1.

S2.

S3.

S6.

S7.

S8.

S9.

S10.

S11.

S12.

S13.

$\mathrm{S} 14$

S15.

S16.

S17.

S18.

S19.

S20.

$\mathrm{S} 21$

S22.

S23.

S24.

S25.

S26.

S27.

S28.

S29.

S30.

S31

S32.

S33.

S34.

S35.

S36.
Table of Contents

Table of Contents Continued

Cloning of TgDHFR

Table of Elemental Analysis

${ }^{1} \mathrm{H}$ NMR of compound $\mathbf{5}$

${ }^{13} \mathrm{C}$ NMR of compound 5

${ }^{1} \mathrm{H}$ NMR of compound $\mathbf{6}$

${ }^{13} \mathrm{C}$ NMR of compound 6

${ }^{1} \mathrm{H}$ NMR of compound 7

${ }^{13} \mathrm{C}$ NMR of compound 7

${ }^{1} \mathrm{H}$ NMR of compound 8

${ }^{13} \mathrm{C}$ NMR of compound 8

${ }^{1} \mathrm{H}$ NMR of compound 9

${ }^{13} \mathrm{C}$ NMR of compound $\mathbf{9}$

${ }^{1} \mathrm{H}$ NMR of compound $\mathbf{1 0}$

${ }^{13} \mathrm{C}$ NMR of compound $\mathbf{1 0}$

${ }^{1} \mathrm{H}$ NMR of compound $\mathbf{1 3}$

${ }^{13} \mathrm{C}$ NMR of compound 13

${ }^{1} \mathrm{H}$ NMR of compound 14

${ }^{13} \mathrm{C}$ NMR of compound 14

${ }^{1} \mathrm{H}$ NMR of compound 15

${ }^{13} \mathrm{C}$ NMR of compound $\mathbf{1 5}$

${ }^{1} \mathrm{H}$ NMR of compound $\mathbf{1 6}$

${ }^{13} \mathrm{C}$ NMR of compound $\mathbf{1 6}$

${ }^{1} \mathrm{H}$ NMR of compound $\mathbf{1 9}$

${ }^{13} \mathrm{C}$ NMR of compound $\mathbf{1 9}$

${ }^{1} \mathrm{H}$ NMR of compound 20

${ }^{13} \mathrm{C}$ NMR of compound 20

${ }^{1} \mathrm{H}$ NMR of compound $\mathbf{2 1}$

${ }^{13} \mathrm{C}$ NMR of compound 21

${ }^{1} \mathrm{H}$ NMR of compound 23

${ }^{13} \mathrm{C}$ NMR of compound 23

${ }^{1} \mathrm{H}$ NMR of compound 24

${ }^{13} \mathrm{C}$ NMR of compound 24 
S37.

S38.

S39.

S40.

S41

S42.

S43.

S44

S45.

S46.

S47.

S48.

S49.

S50.

S51

S52.

S53........

S54.

S55

S56.
${ }^{1} \mathrm{H}$ NMR of compound 25

${ }^{13} \mathrm{C}$ NMR of compound 25

${ }^{1} \mathrm{H}$ NMR of compound 26

${ }^{13} \mathrm{C}$ NMR of compound 26

${ }^{1} \mathrm{H}$ NMR of compound 27

${ }^{13} \mathrm{C}$ NMR of compound 27

${ }^{1} \mathrm{H}$ NMR of compound 28

${ }^{13} \mathrm{C}$ NMR of compound $\mathbf{2 8}$

${ }^{1} \mathrm{H}$ NMR of compound 29

${ }^{13} \mathrm{C}$ NMR of compound 29

${ }^{1} \mathrm{H}$ NMR of compound 30

${ }^{13} \mathrm{C}$ NMR of compound 30

${ }^{1} \mathrm{H}$ NMR of compound 31

${ }^{13} \mathrm{C}$ NMR of compound 31

${ }^{1} \mathrm{H}$ NMR of compound 32

${ }^{13} \mathrm{C}$ NMR of compound 32

${ }^{1} \mathrm{H}$ NMR of compound 37

${ }^{13} \mathrm{C}$ NMR of compound 37

${ }^{1} \mathrm{H}$ NMR of compound 38

${ }^{13} \mathrm{C}$ NMR of compound 38 


\section{Cloning TgDHFR:}

The TgDHFR gene was PCR amplified (Turbo PFU Ultra Taq Polymerase, Stratagene) from an expression vector containing T.gondii DHFR-TS (GenBank \#L08489). The DHFR protein containing amino acid sequence (AAB00163) was determined by multiple sequence alignment of 16 DHFR protein using EsPript (ref: Gouet et al., Nucleic Acids Research, 31(13): 3320, 2003). The gene including 690 nucleotides and encoding a 230 residue protein was PCR amplified using the forward primer 5'- AACCATGCCATGGGACAGAAACCGGTGTGTC-3' and the reverse primer 5'- CAGGAAGATCTCTTCTCGAGAACCACAAAGTCTG-3' and standard PCR conditions with an annealing temperature of $60^{\circ} \mathrm{C}$. The gene was inserted into the pQE-60 vector (Qiagen) using the restriction endonuclease sites NcoI and BglII at the N and C- terminus, respectively.

Additional cloning using Splicing by Overlap Extension (SOE) (ref: Warrens et al., Gene, 186: 29-35, 1997) was used to replace a 28 residue loop region (residues 4370) with a 5 residue region that excluded the last 23 residues of the defined loop region (residues 48-70) and rendered a 205 residue protein. Briefly, two additional primers were used including the above primers for three separate PCR reactions. The reverse primer 5'GGCGTTGAATCTCTTGCCACTGGCTTCTT-CGGGCGTC-3' was used with the forward primer mentioned above, to amplify the sequence upstream of the loop region. This reverse primer contains a 5' 19 -nucleotide overlap with the region downstream of the loop region. The forward primer 5'- GACGCCCGAAGAAGCCAGTGGCAAGAGATTCAACGCC -3 ' was used to amplify the gene downstream of the loop region using the reverse primer mentioned above, also containing a 19-nucleotide complementary 
region to the desired sequence upstream of the loop region. PCR products from the first two reactions were gel purified and a small amount from each was combined and used as template for a third PCR reaction with only the first two primers mentioned above and an annealing temperature of $65^{\circ} \mathrm{C}$. Amplified product was purified by phenol chloroform extraction and ethanol precipitation. The expression vector was created by digesting the pQE-60 vector and insert with the restriction endonucleases, NcoI and BglII (New England Biolabs) followed by ligation with T4 DNA ligase (Roche). Competent DH5 $\alpha$ cells (Invitrogen) were transformed with circularized plasmid with insert, recovered and sequenced to ensure no errors resulted from the PCR reaction. Competent M15 cells (Qiagen) were transformed with purified plasmid for recombinant protein expression.

M15 cell transformants were grown in Luria Broth (LB) containing $50 \mu \mathrm{g} / \mathrm{mL}$ ampicillin and $30 \mu \mathrm{g} / \mathrm{mL}$ kanamycin for selection of the expression plasmid and the pREP4 plasmid, respectively. Cells were grown at $37{ }^{\circ} \mathrm{C}$, shaking at $250 \mathrm{rpm}$ and induced with $1 \mathrm{mM}$ isopropyl- $\beta$-D-thiogalactopyranoside (IPTG) at mid-logarithmic phase of growth. Recombinant protein overexpression was extended for 6 hours. Cells were harvested by centrifugation at $10,000^{*} \mathrm{~g}$ for 10 minutes and placed at $-80^{\circ} \mathrm{C}$ until cell lysis.

The cell pellet from 2L of cells was solubilized in Bug Buster (Novagen) and placed on an orbital shaker for 20 minutes at room temperature for chemical lysis. The insoluble fraction of the cells was retrieved by centrifugation at 50,000*g for 20 minutes and the supernatant was decanted. The insoluble pellet was washed two times by resuspension in $25 \mathrm{~mL}$ in $20 \mathrm{mM} \mathrm{KH} \mathrm{PO}_{4} \mathrm{pH}$ 7, $10 \mathrm{mM}$ DTT, $0.2 \mathrm{mM}$ EDTA and $20 \%$ glycerol (Buffer A) with $1 \mathrm{mM}$ guanidine $\mathrm{HCl}$ and centrifugation. The insoluble fraction 
of the cells was harvested by resuspension to a total volume of $20 \mathrm{~mL}$ Buffer $\mathrm{A}$ in the presence of $6 \mathrm{M}$ guanidine $\mathrm{HCl}$ and $2 \mathrm{mM}$ phenylmethylsulfonylfluoride (PMSF). DNase was added $(30 \mu \mathrm{L})$ to reduce viscosity and the solution was gently mixed at $4{ }^{\circ} \mathrm{C}$ for one hour prior to centrifugation as above. The insoluble extract was placed into a fresh pre-chilled centrifuge tube and centrifuged a second time to remove any insoluble debris. The supernatant was filtered $(0.45 \mu \mathrm{m}$ filter (Millipore)) prior to refolding.

Using a 0.25 gauge needle and syringe, $10 \mathrm{~mL}$ of insoluble protein suspension was refolded by adding dropwise to $200 \mathrm{~mL}$ of Buffer $\mathrm{A}+0.2 \mathrm{M} \mathrm{KCl}$ at $4{ }^{\circ} \mathrm{C}$ with vigorous stirring. Once protein is added to buffer, stirring speed was reduced to slow for 2 hours. The re-folded protein solution was centrifuged at $20,000 * \mathrm{~g}$ for 20 minutes to remove unfolded protein and filtered through a $0.2 \mu \mathrm{m}$ bottle-top filter (Millipore) before loading onto an econo-column (Biorad) with methotrexate affinity resin (Sigma) for protein purification to homogeneity.

Refolded protein was loaded onto a $9 \mathrm{~mL}$ methotrexate affinity column after equilibration using a flow rate of $0.5 \mathrm{~mL} /$ minute. The column was washed with Buffer $\mathrm{A}+0.5 \mathrm{M} \mathrm{KCl}$ until no protein appeared in the effluent as determined by $\mathrm{OD}_{280}$ measurements. The column was re-equilibrated with 5 column volumes of Buffer $\mathrm{A}+50$ $\mathrm{mM} \mathrm{KCl}$ and bound protein was eluted with re-equilibration buffer in the presence of 25 mg dihydrofolate (Sigma). Fractions containing pure protein as determined by SDSPAGE analysis and silver stain, were pooled and exchanged into $20 \mathrm{mM}$ TES pH 7, 10 mM DTT, $50 \mathrm{mM} \mathrm{KCl}$ and 20\% glycerol by dialysis. Protein was concentrated to 10 $\mathrm{mg} / \mathrm{mL}$ using a $10 \mathrm{~mL}$ Amicon concentrater and 10K filter paper prior to snap freezing using a dry ice bath. 
Table of Compound Characterization

Tabulated Elemental Analysis

\begin{tabular}{clcccccc}
\hline & & \multicolumn{3}{c}{ Calculated } & \multicolumn{3}{c}{ Found } \\
\hline Compound & Formula & $\% \mathrm{C}$ & $\% \mathrm{H}$ & $\% \mathrm{~N}$ & $\% \mathrm{C}$ & $\% \mathrm{H}$ & $\% \mathrm{~N}$ \\
$\mathbf{5}$ & $\mathrm{C}_{4} \mathrm{H}_{5} \mathrm{IN}_{4}$ & 20.36 & 2.14 & 23.74 & 20.41 & 2.00 & 23.65 \\
$\mathbf{1 5}$ & $\mathrm{C}_{5} \mathrm{H}_{7} \mathrm{IN}_{4}$ & 24.02 & 2.82 & 22.41 & 24.10 & 2.78 & 22.20 \\
$\mathbf{7}$ & $\mathrm{C}_{15} \mathrm{H}_{16} \mathrm{~N}_{4} \mathrm{O}_{3}$ & 59.99 & 5.37 & 18.66 & 59.85 & 5.21 & 18.39 \\
$\mathbf{1 4}$ & $\mathrm{C}_{16} \mathrm{H}_{18} \mathrm{~N}_{4} \mathrm{O}_{3}$ & 61.13 & 5.77 & 17.82 & 61.00 & 5.70 & 18.05 \\
$\mathbf{2 0}$ & $\mathrm{C}_{17} \mathrm{H}_{20} \mathrm{~N}_{4} \mathrm{O}_{3}$ & 62.18 & 6.14 & 17.06 & 62.00 & 6.34 & 17.11 \\
$\mathbf{2 1}$ & $\mathrm{C}_{18} \mathrm{H}_{22} \mathrm{~N}_{4} \mathrm{O}_{3}$ & 63.14 & 6.48 & 16.36 & 63.06 & 6.38 & 16.21 \\
$\mathbf{2 4}$ & $\mathrm{C}_{16} \mathrm{H}_{18} \mathrm{~N}_{4} \mathrm{O}_{4}$ & 58.17 & 5.49 & 16.96 & 57.85 & 5.60 & 16.75 \\
$\mathbf{2 7}$ & $\mathrm{C}_{17} \mathrm{H}_{20} \mathrm{~N}_{4} \mathrm{O}_{4}$ & 59.29 & 5.85 & 16.27 & 59.19 & 5.80 & 16.16 \\
$\mathbf{1 0}$ & $\mathrm{C}_{15} \mathrm{H}_{20} \mathrm{~N}_{4} \mathrm{O}_{3}$ & 59.20 & 6.62 & 18.41 & 59.17 & 6.52 & 18.12 \\
\hline
\end{tabular}


<smiles>Nc1ncc(I)c(N)n1</smiles>

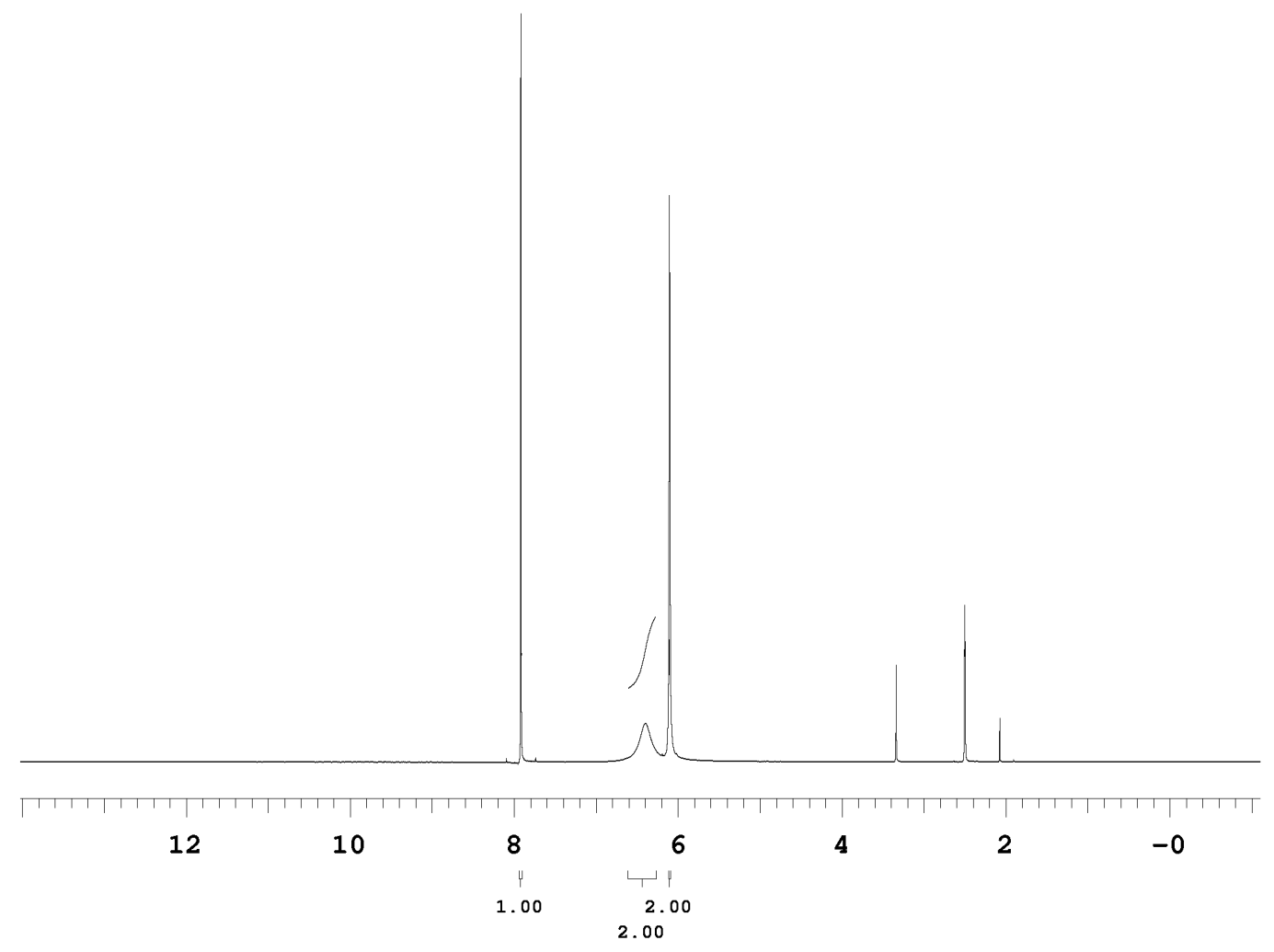


<smiles>Nc1ncc(I)c(N)n1</smiles>

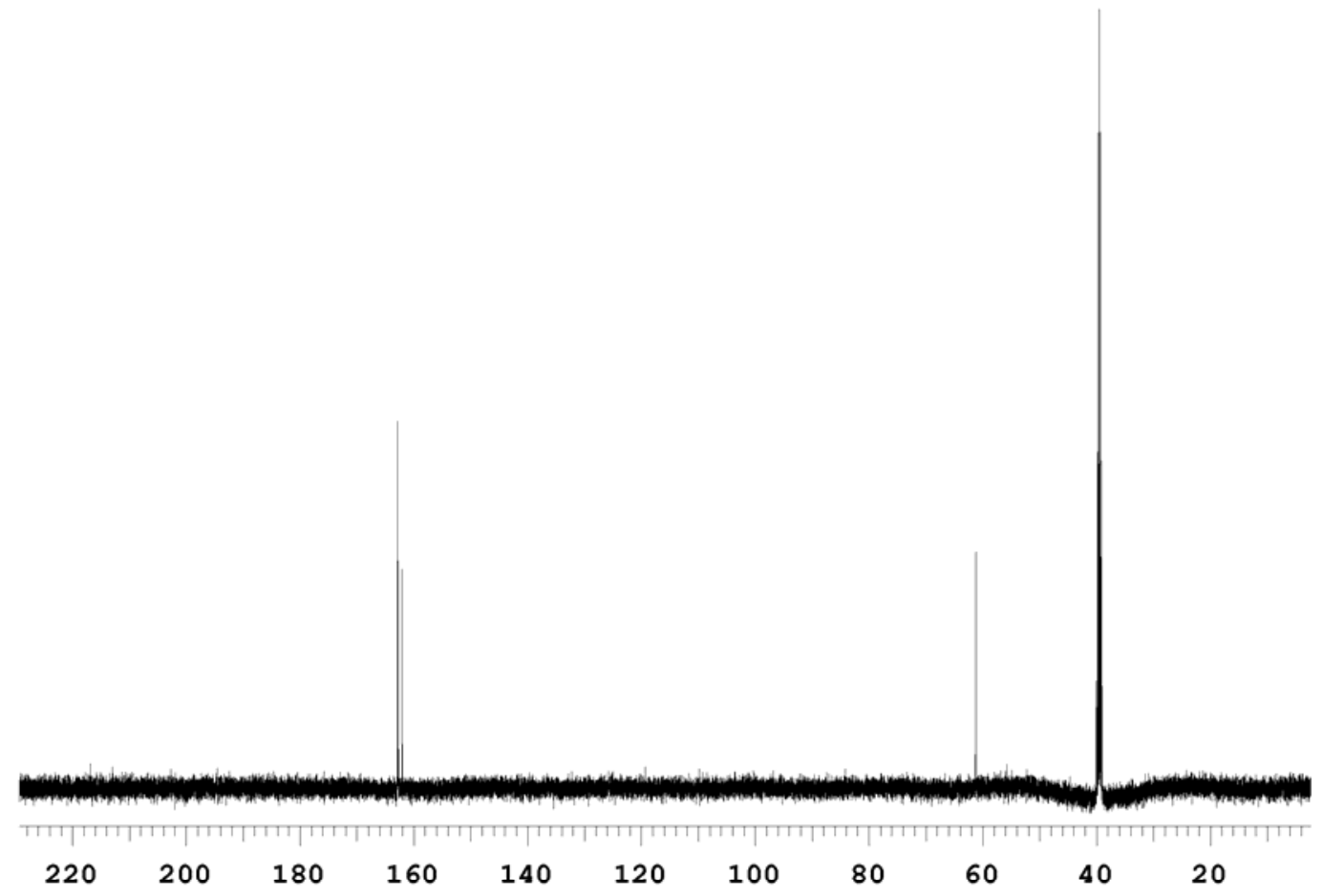



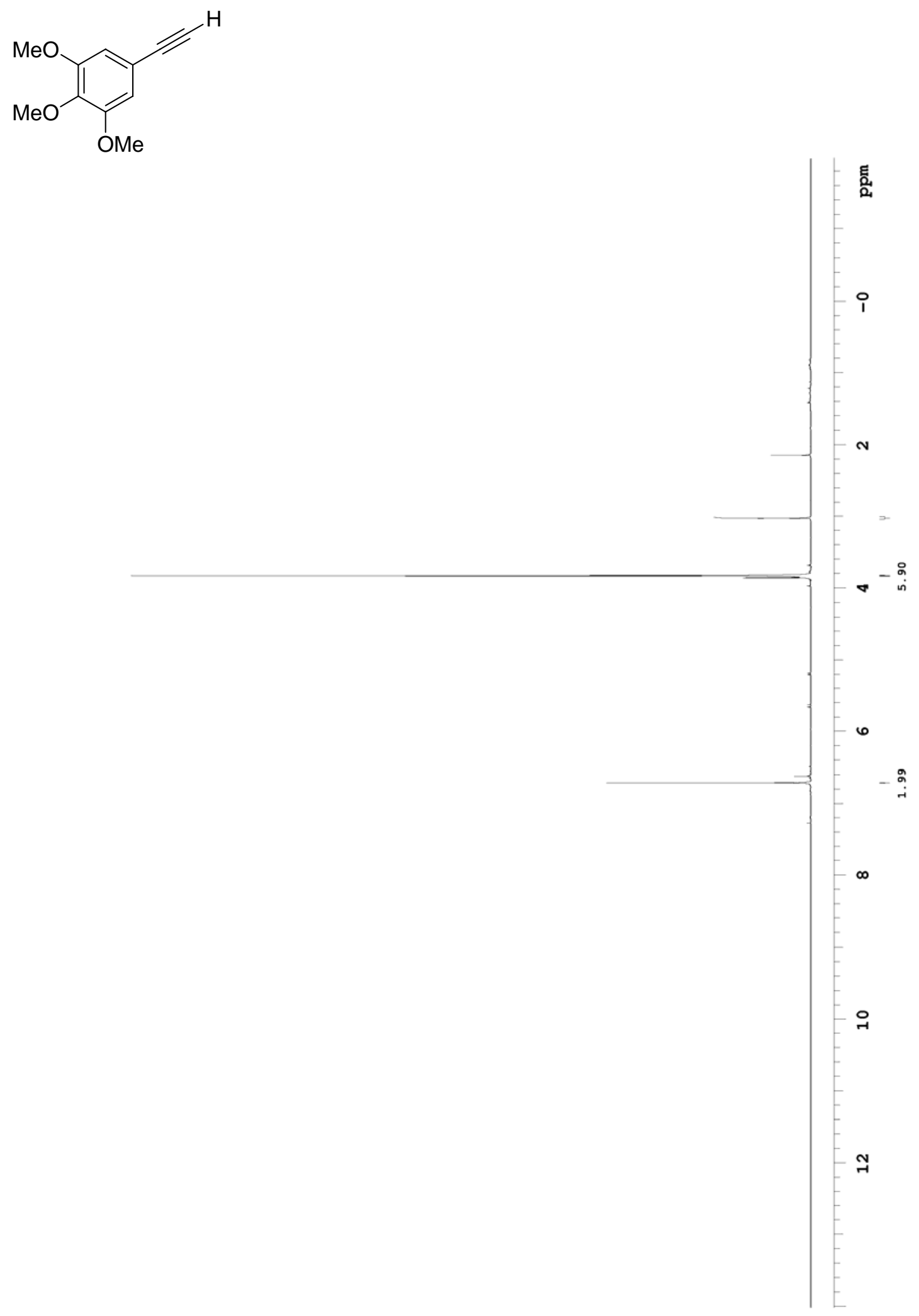

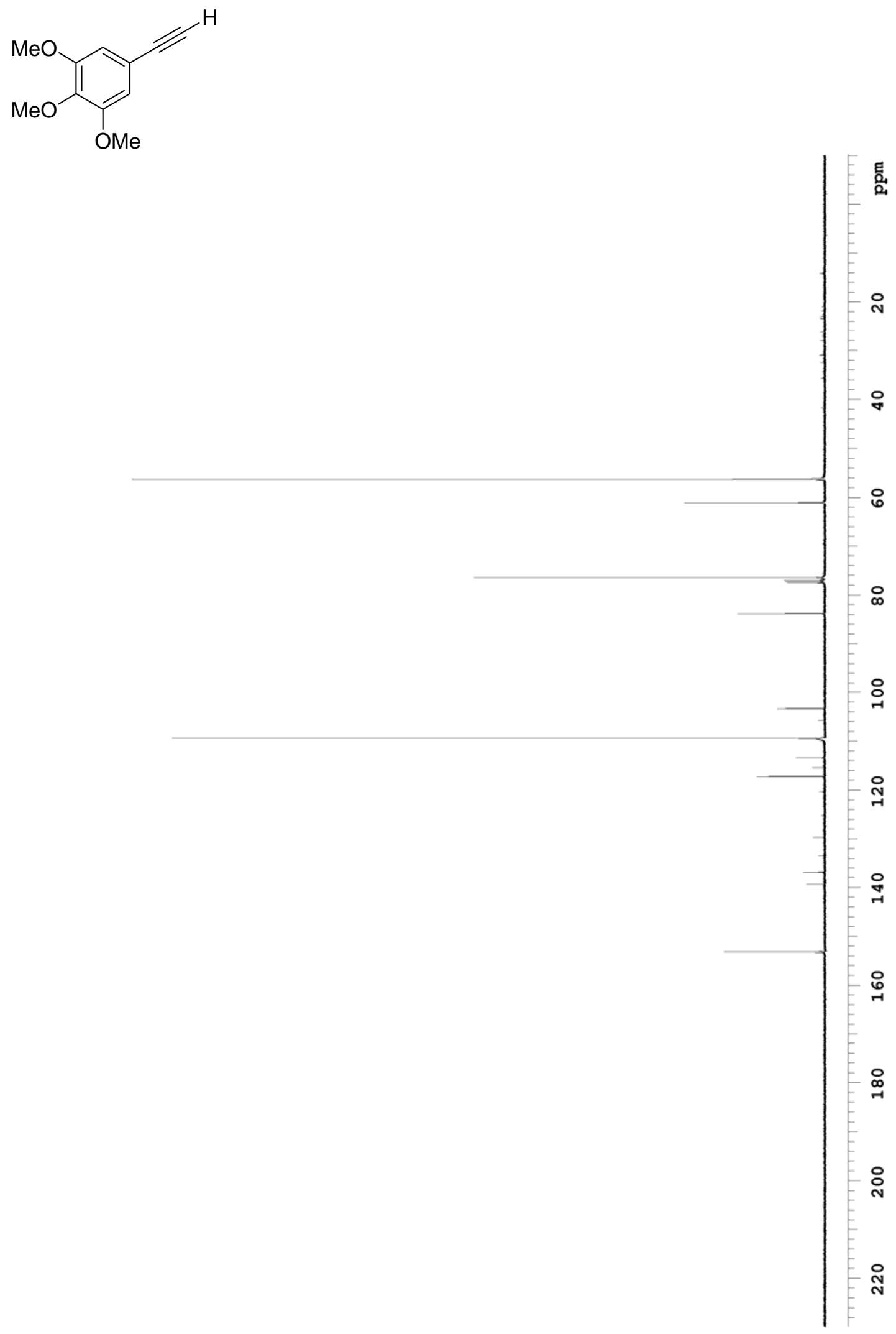
<smiles>COc1cc(C#Cc2cnc(N)nc2N)cc(OC)c1OC</smiles>

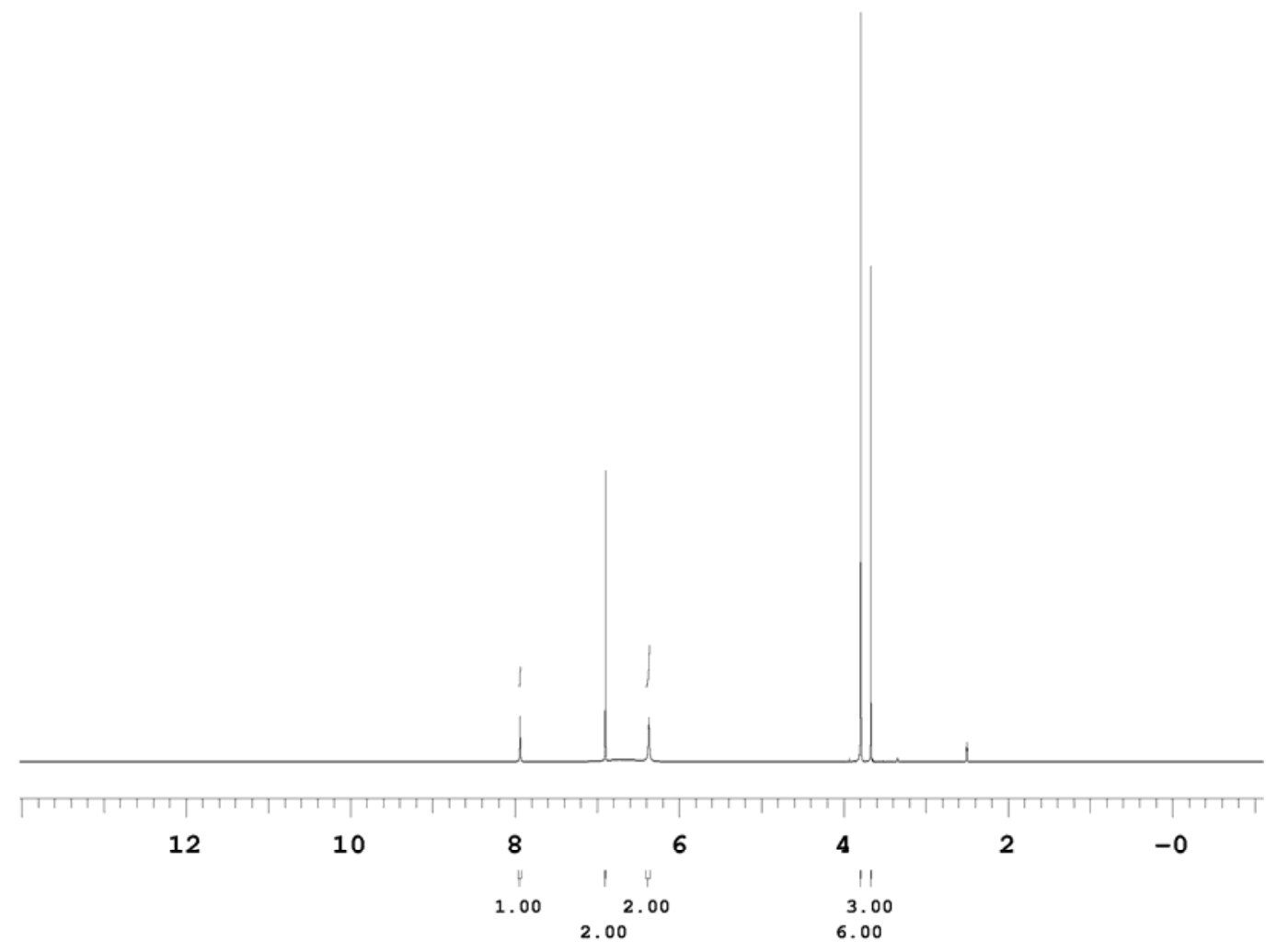


<smiles>COc1cc(C#Cc2cnc(N)nc2N)cc(OC)c1OC</smiles>

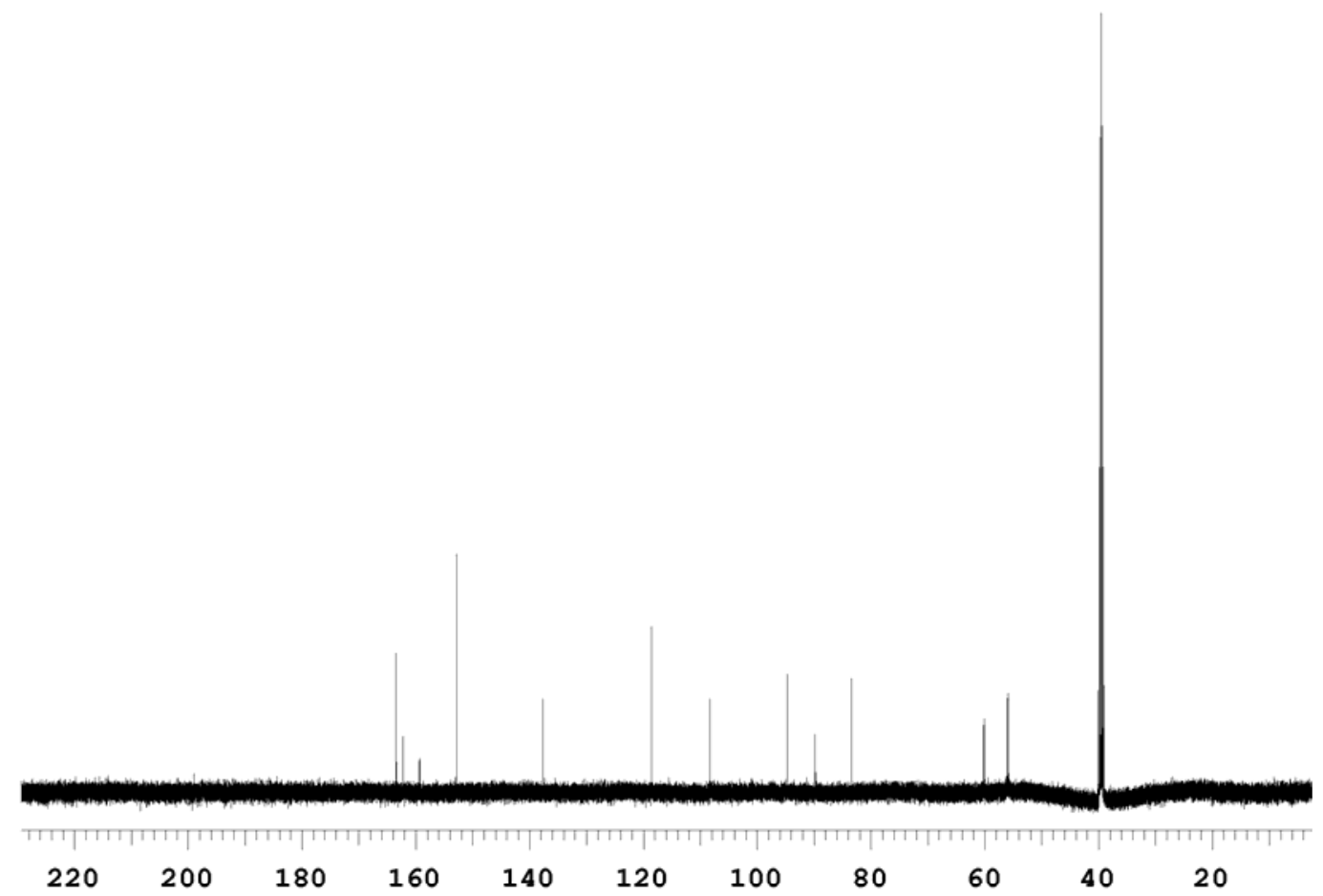




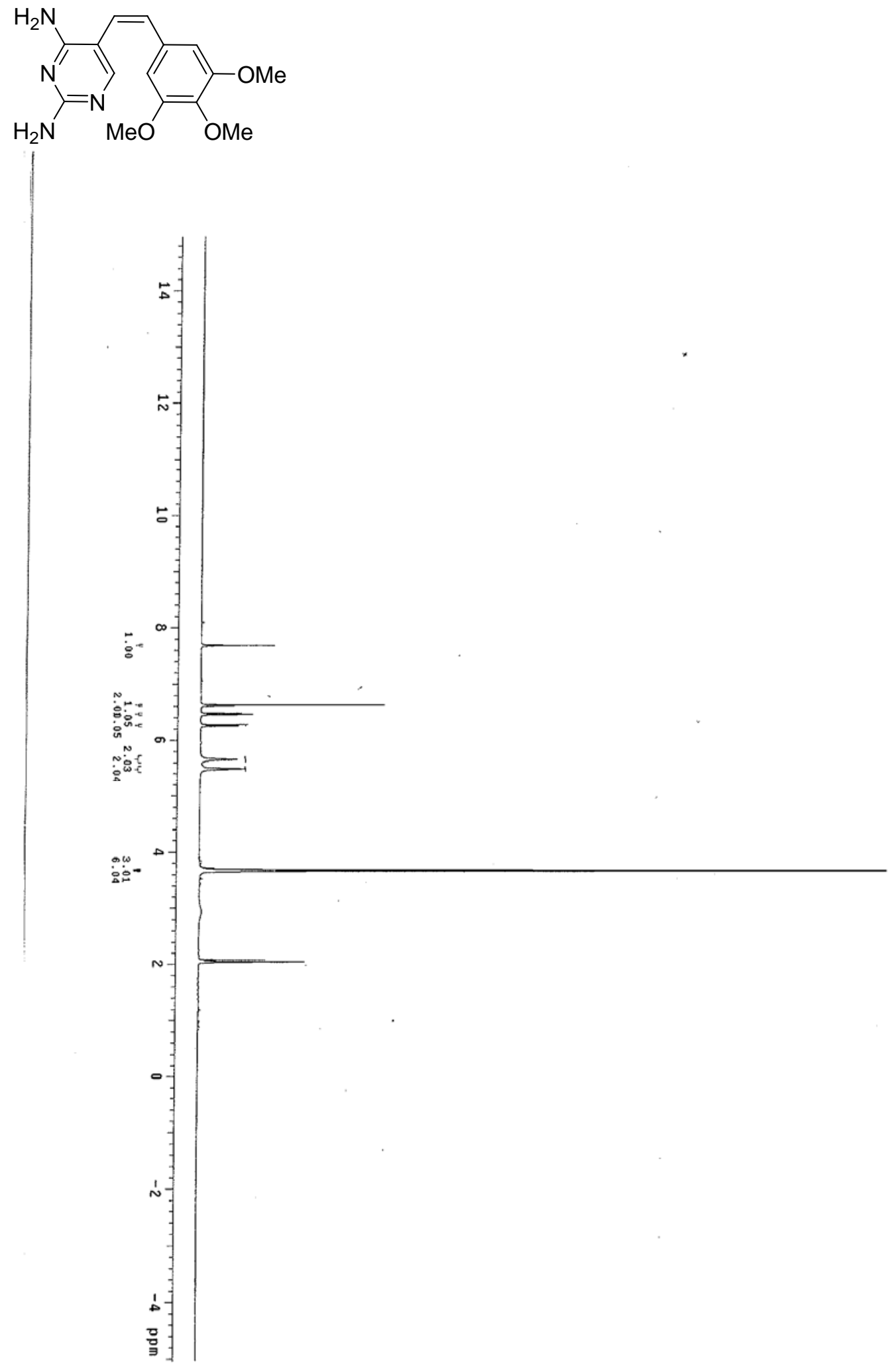


<smiles>COc1cc(/C=C\c2cnc(N)nc2N)cc(OC)c1OC</smiles>

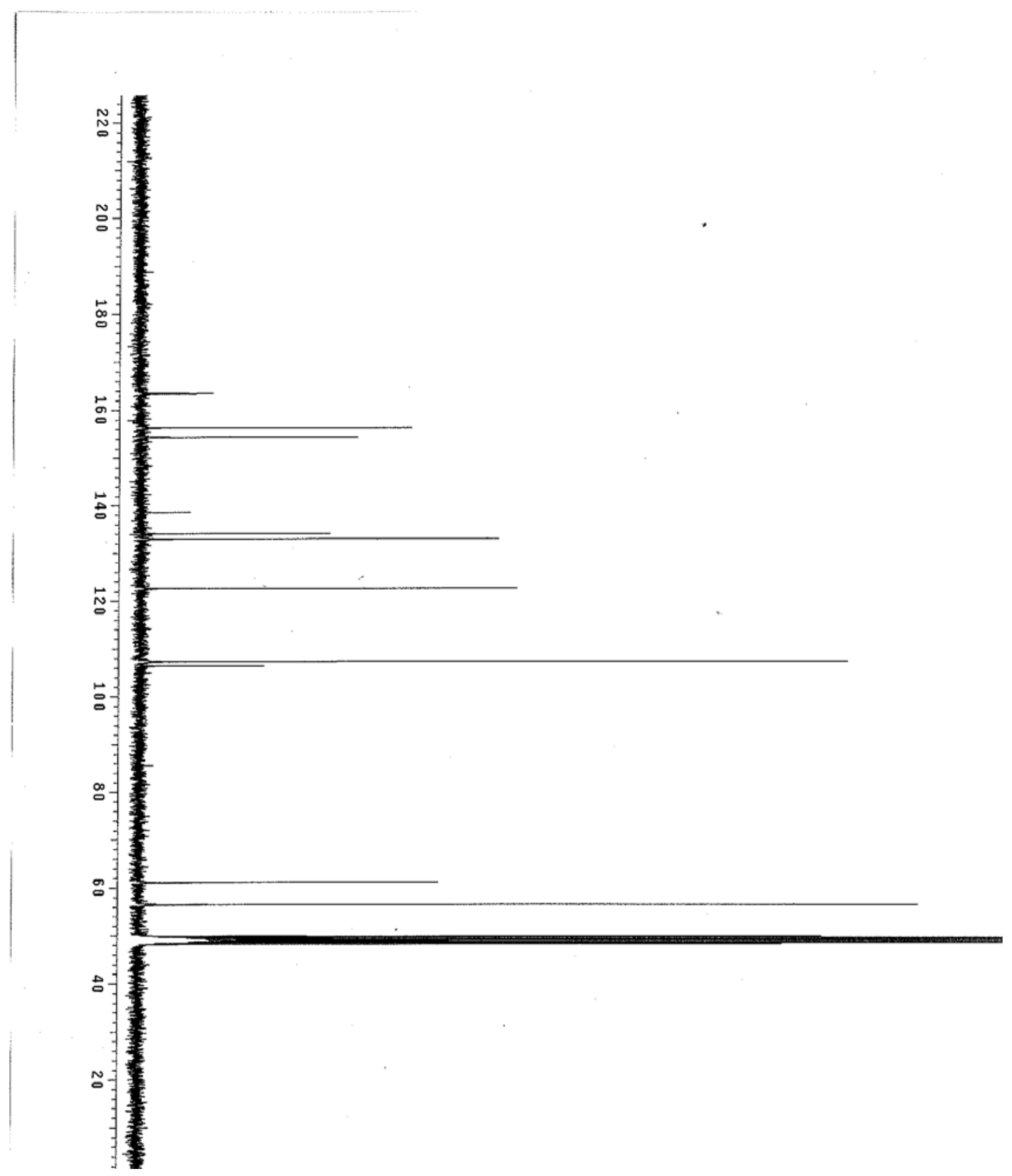




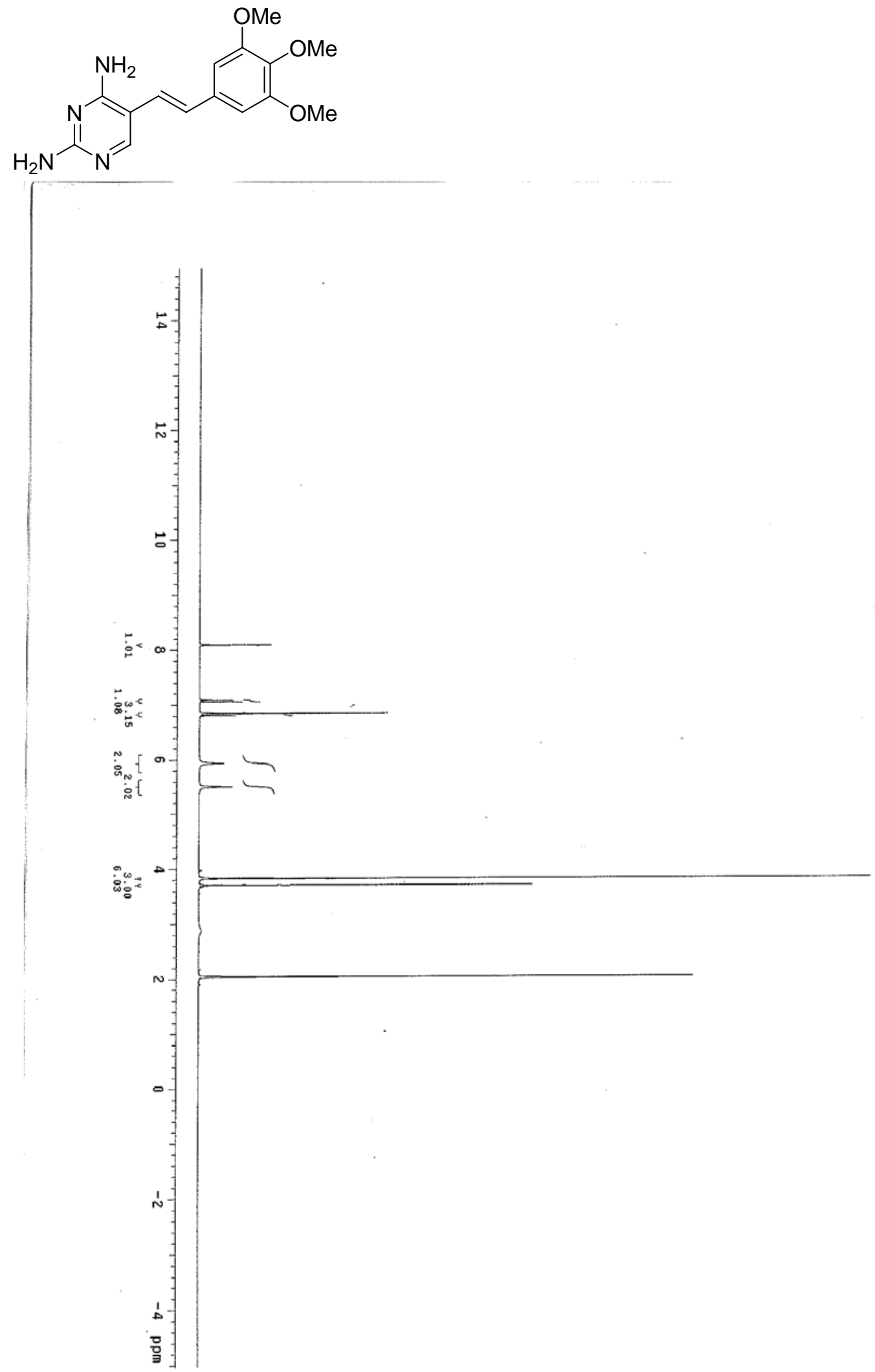



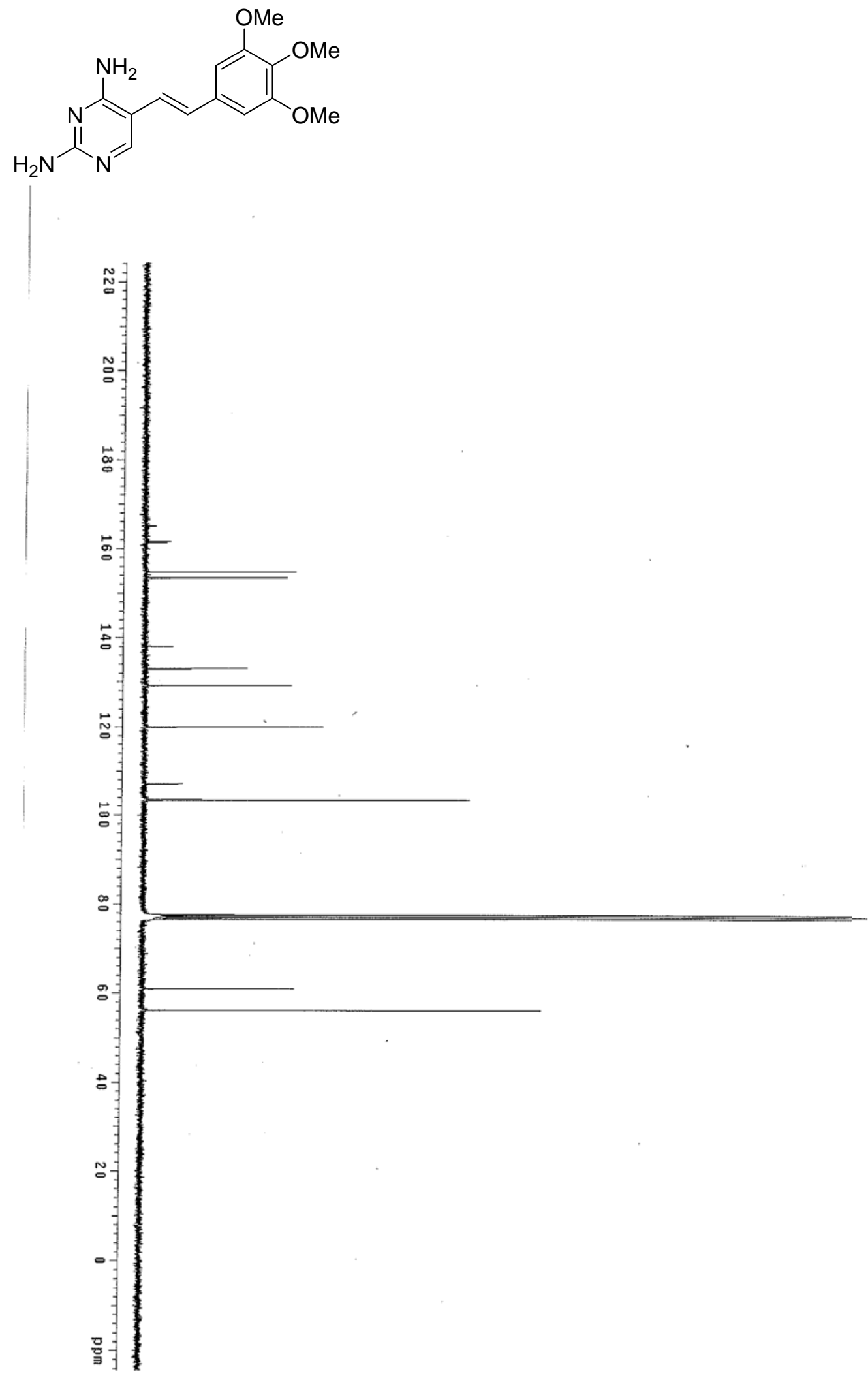
<smiles>COc1cc(CCc2cnc(N)nc2N)cc(OC)c1OC</smiles>

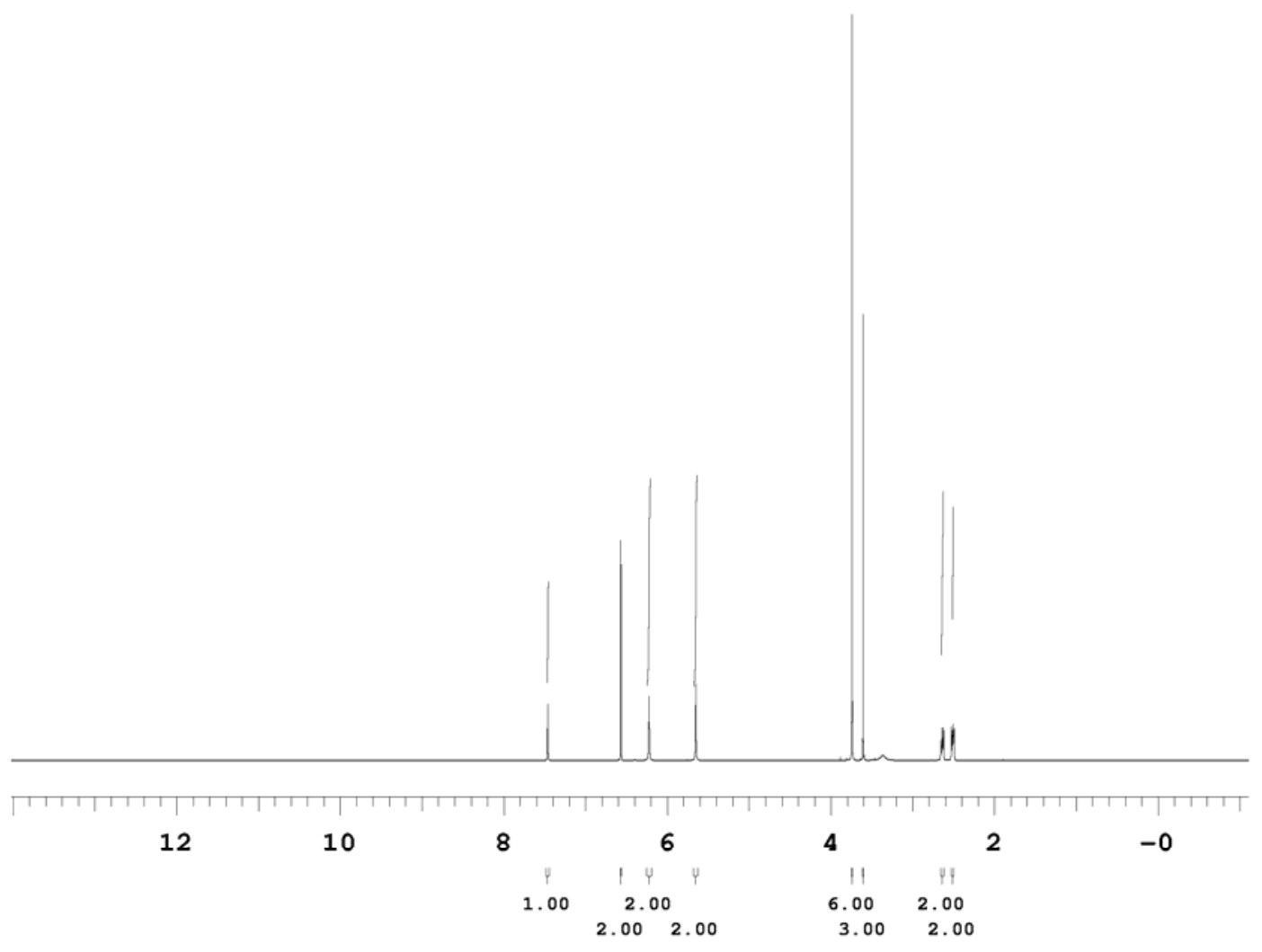


<smiles>COc1cc(CCc2cnc(N)nc2N)cc(OC)c1OC</smiles>

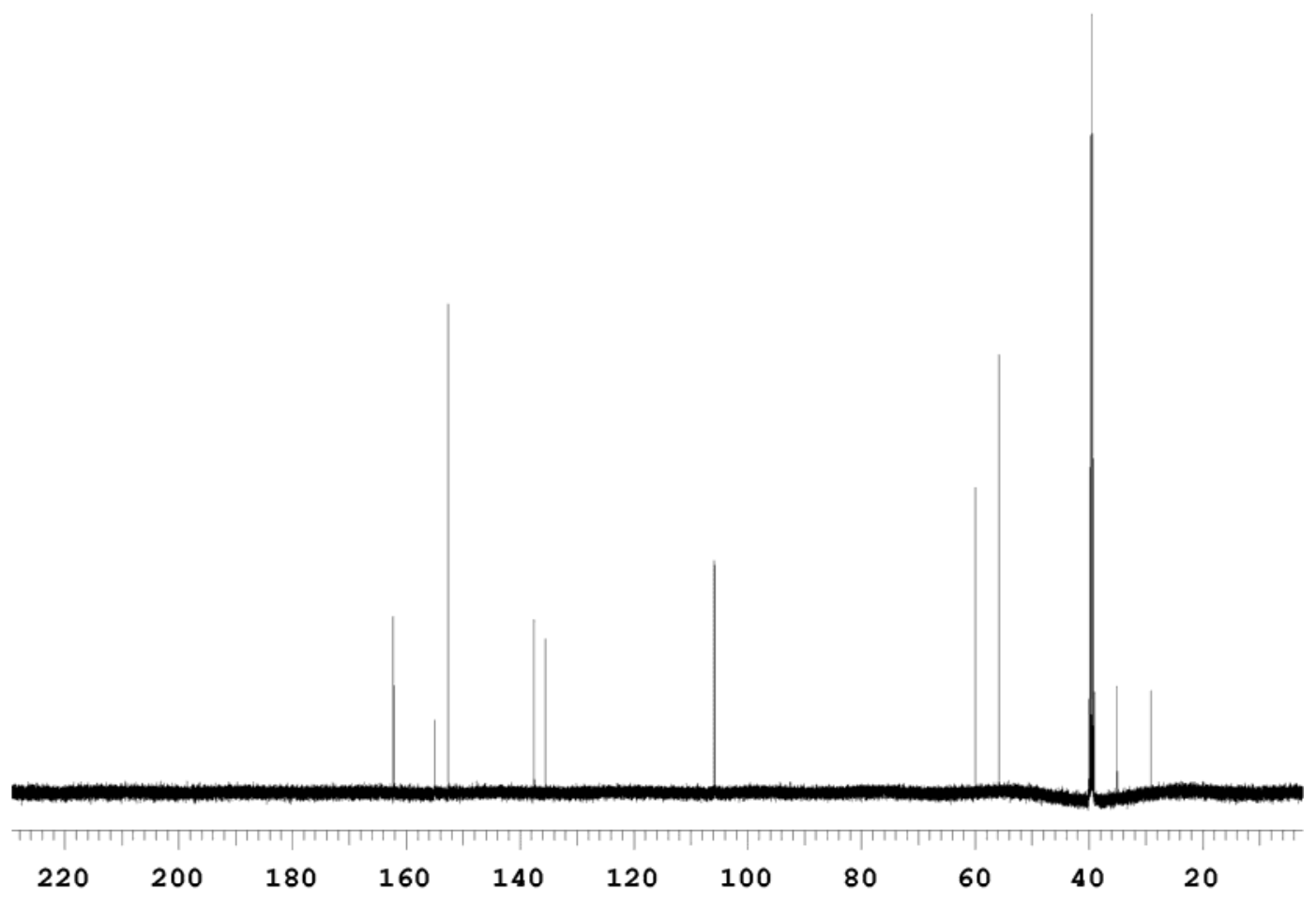



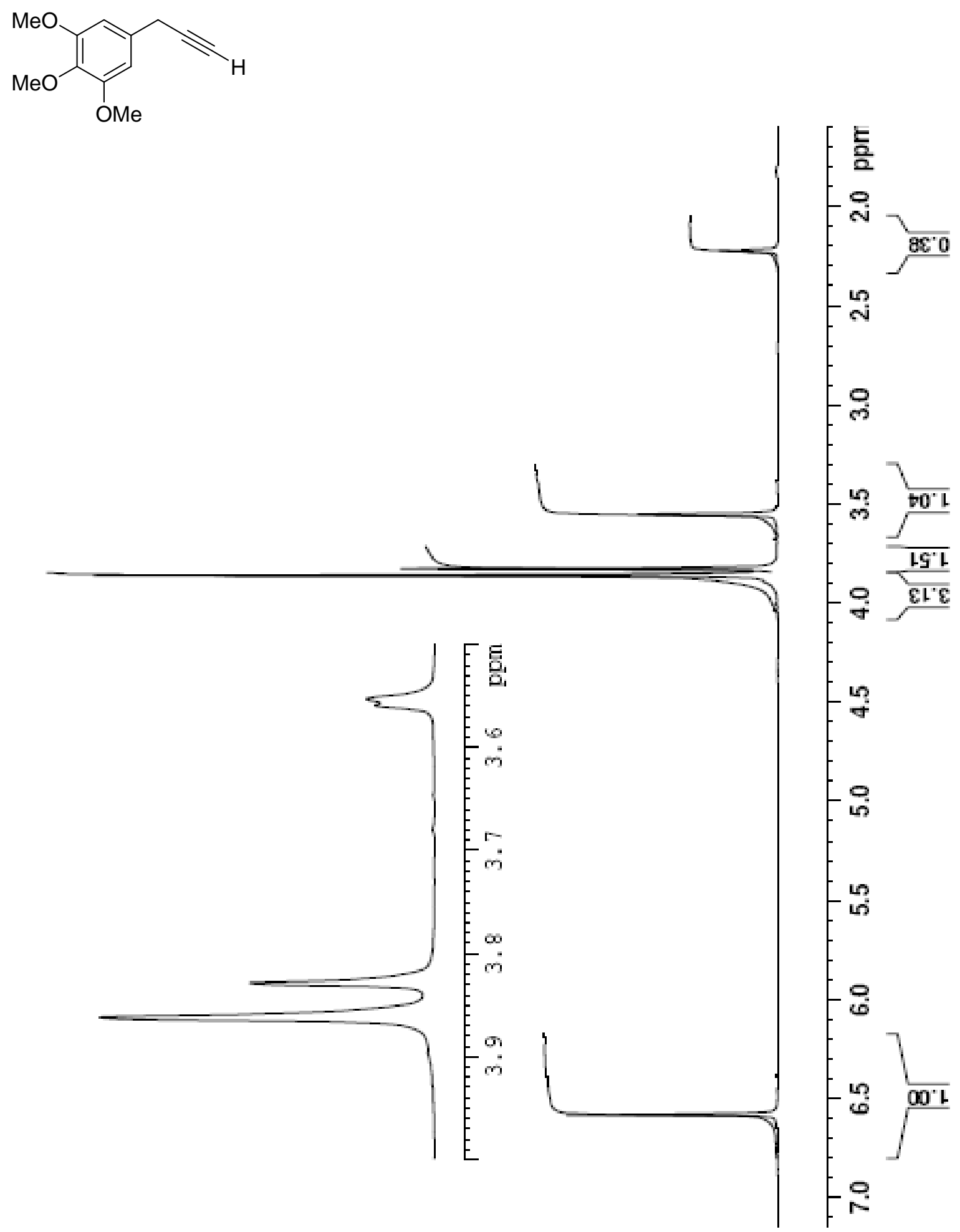

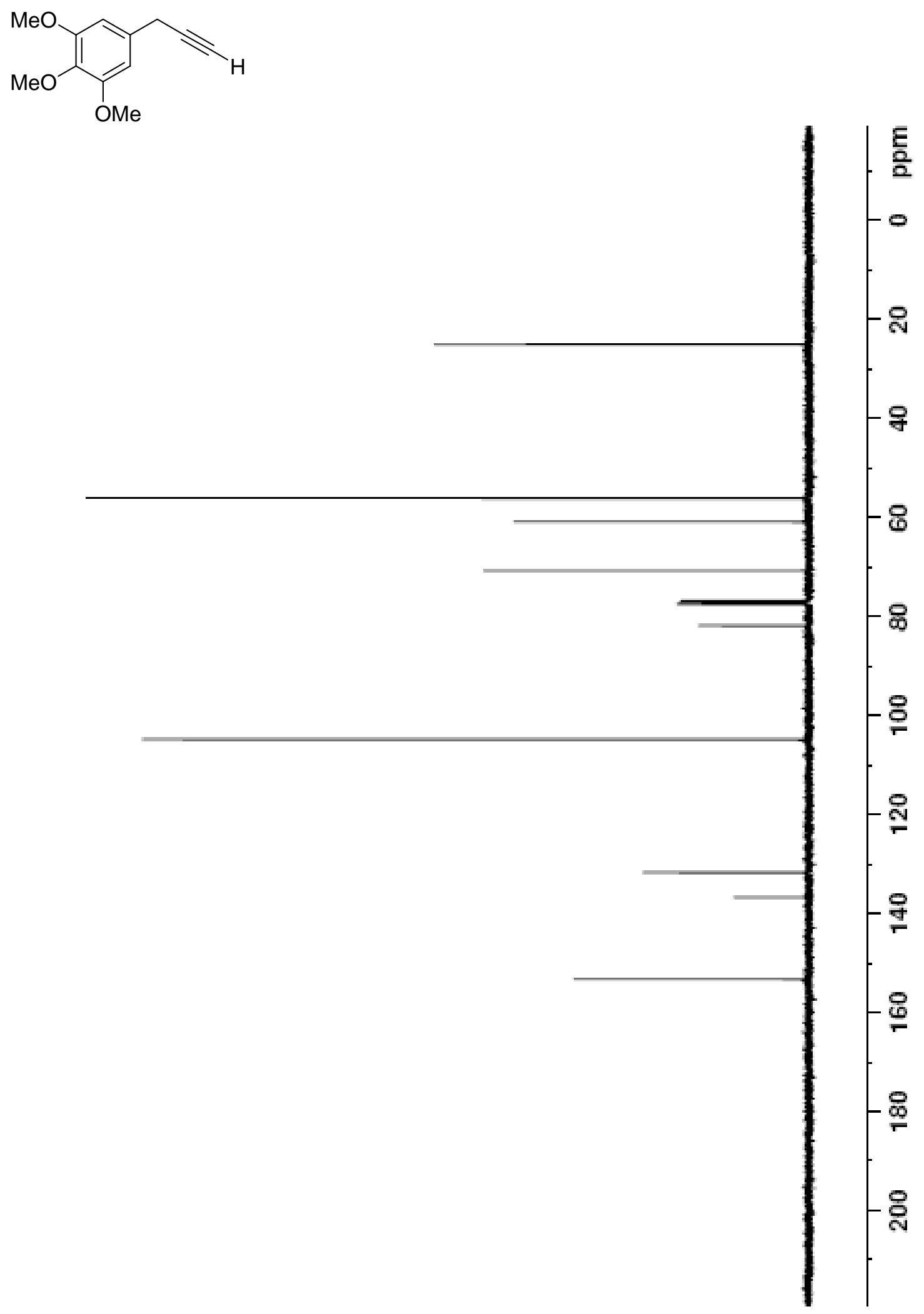
<smiles>COc1cc(CC#Cc2cnc(N)nc2N)cc(OC)c1OC</smiles>

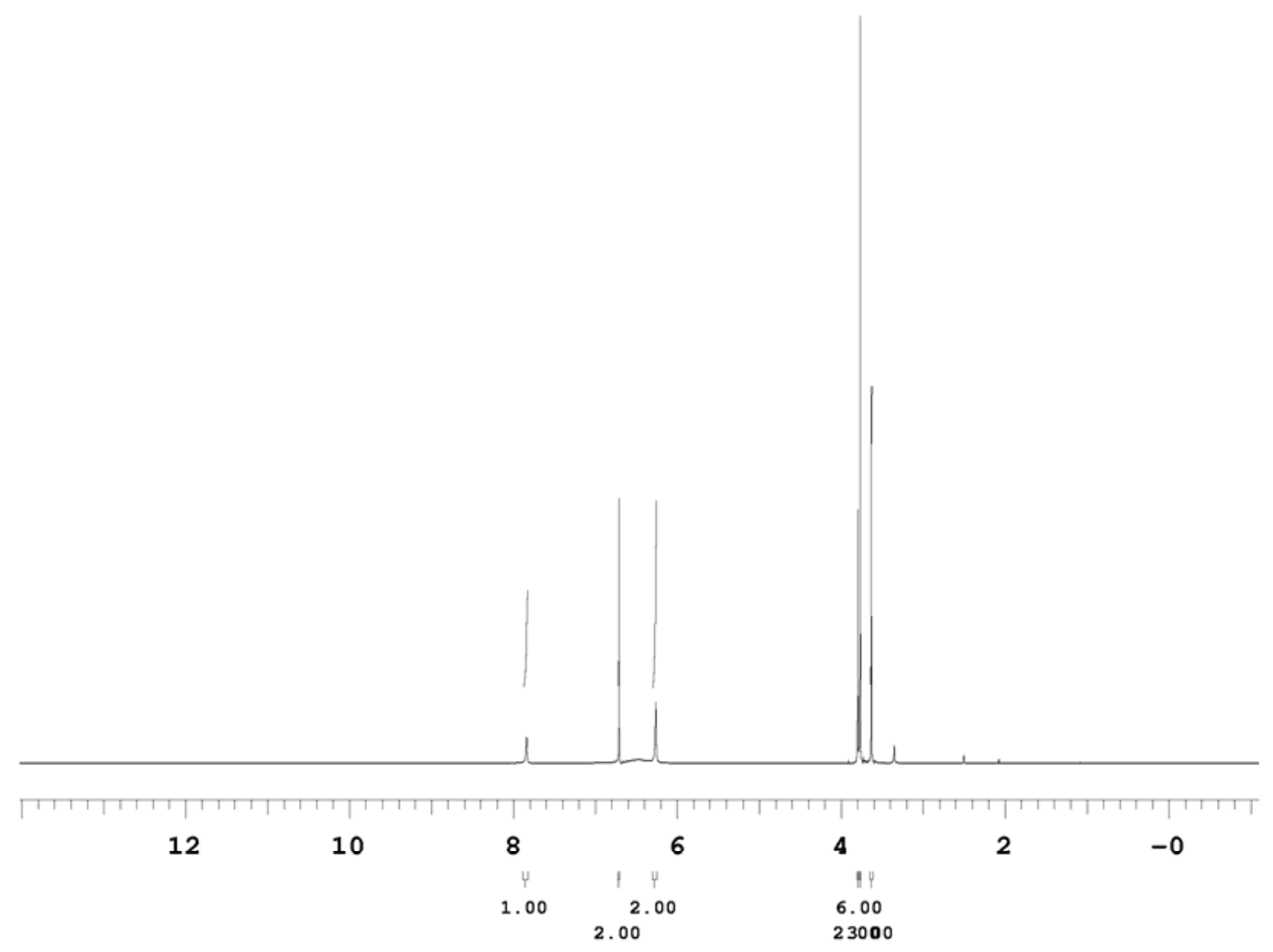


<smiles>COc1cc(CC#Cc2cnc(N)nc2N)cc(OC)c1OC</smiles>

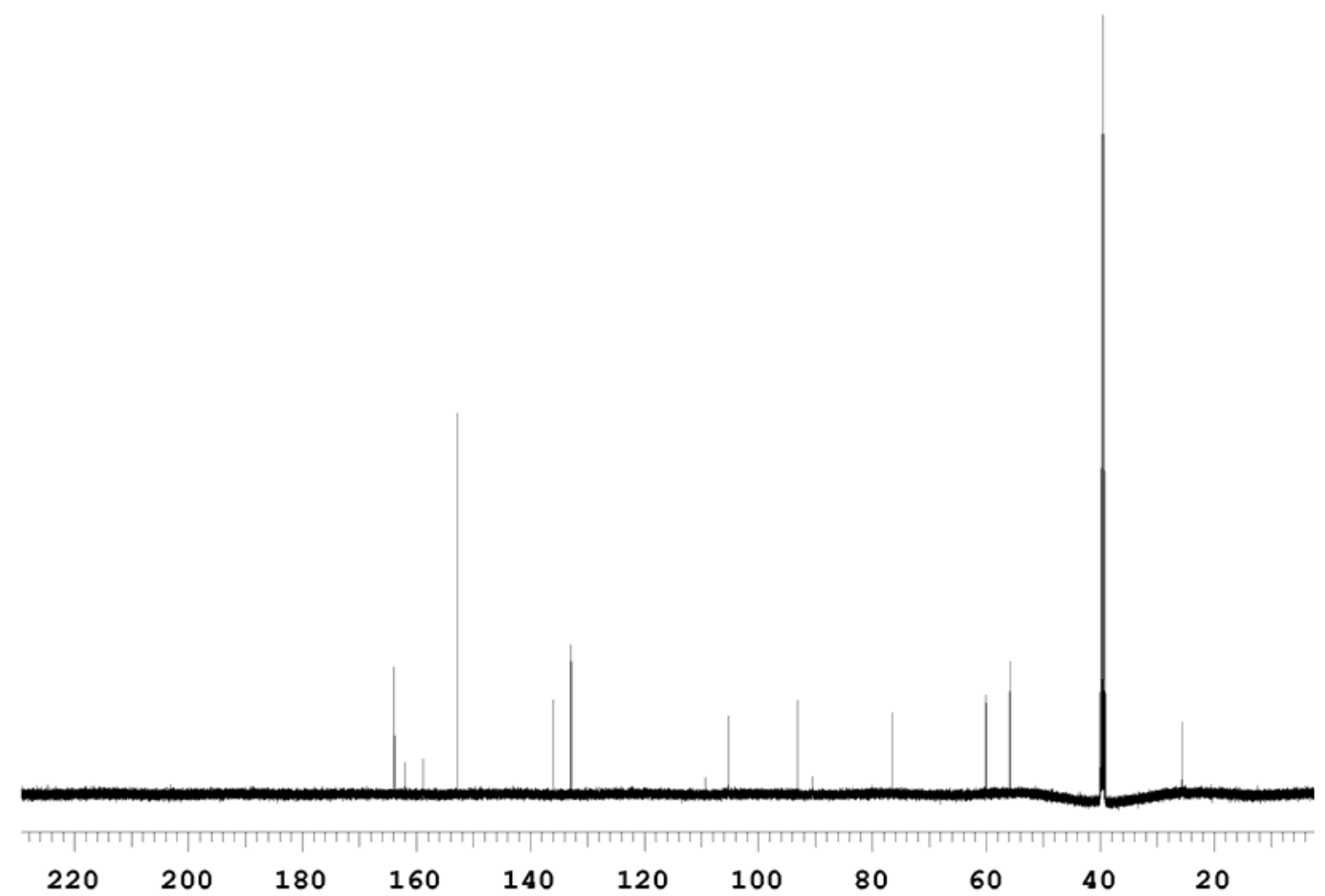


<smiles>Cc1nc(N)nc(N)c1I</smiles>

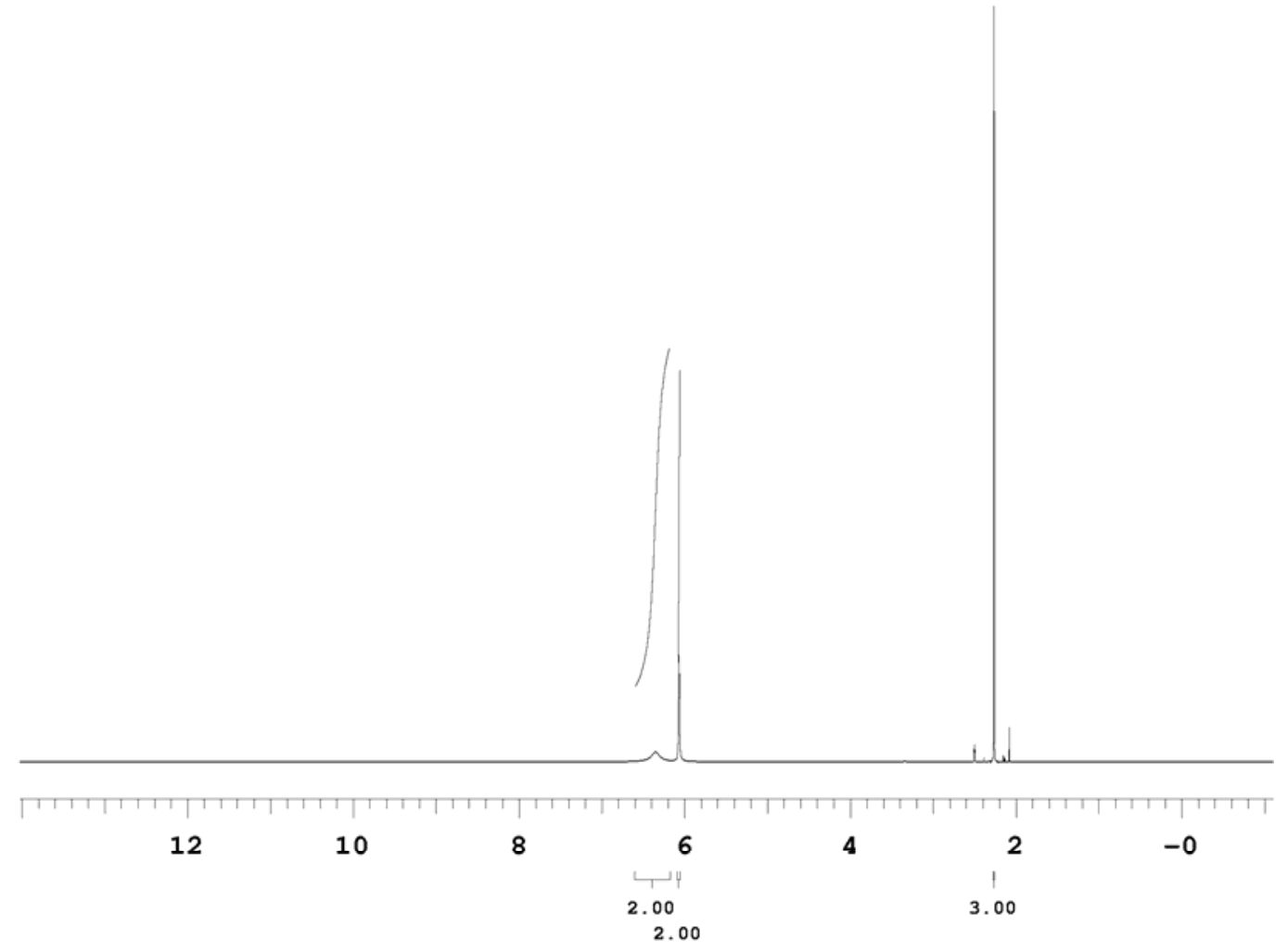


<smiles>Cc1nc(N)nc(N)c1I</smiles>

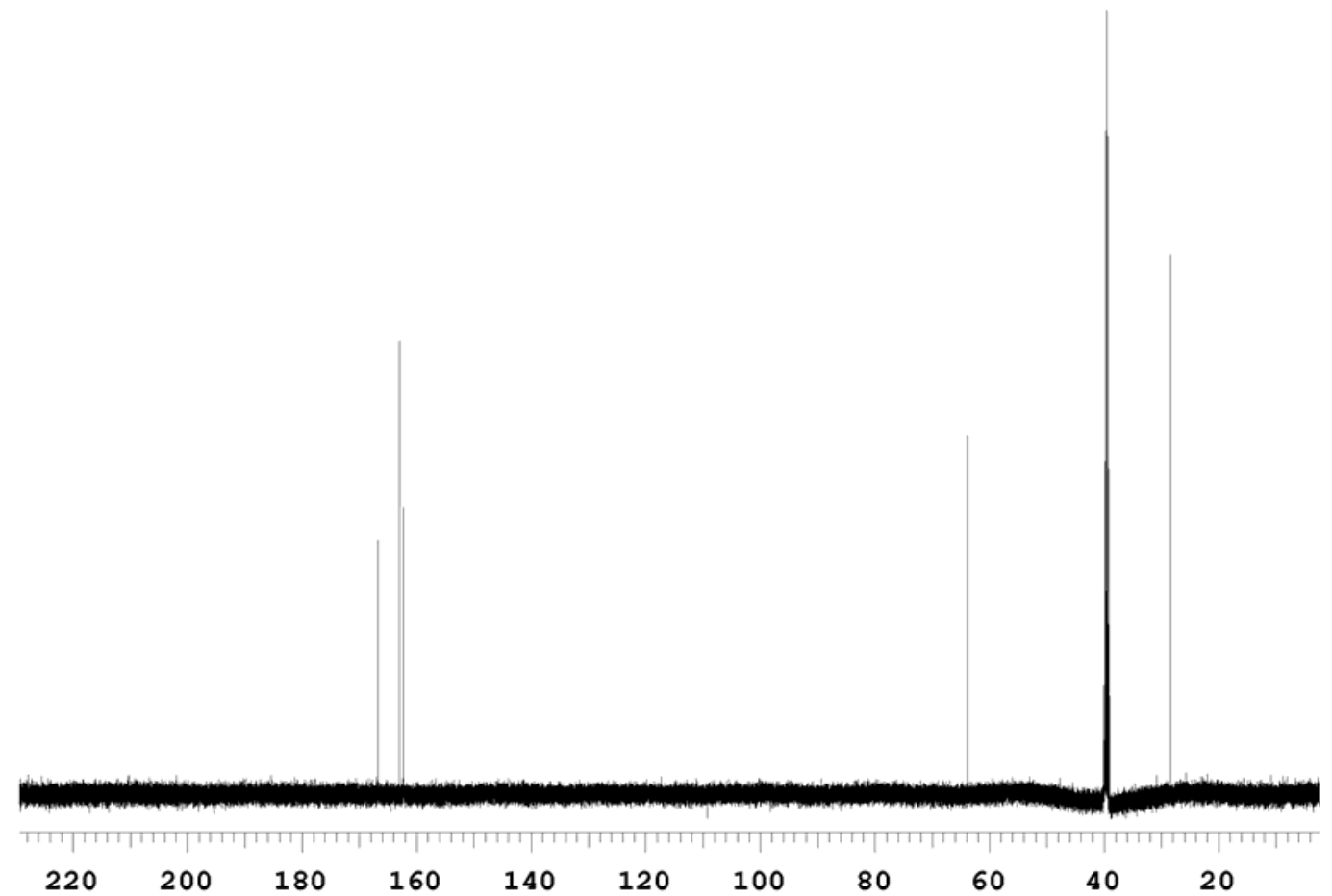


<smiles>COc1cc(CC#Cc2c(C)nc(N)nc2N)cc(OC)c1OC</smiles>

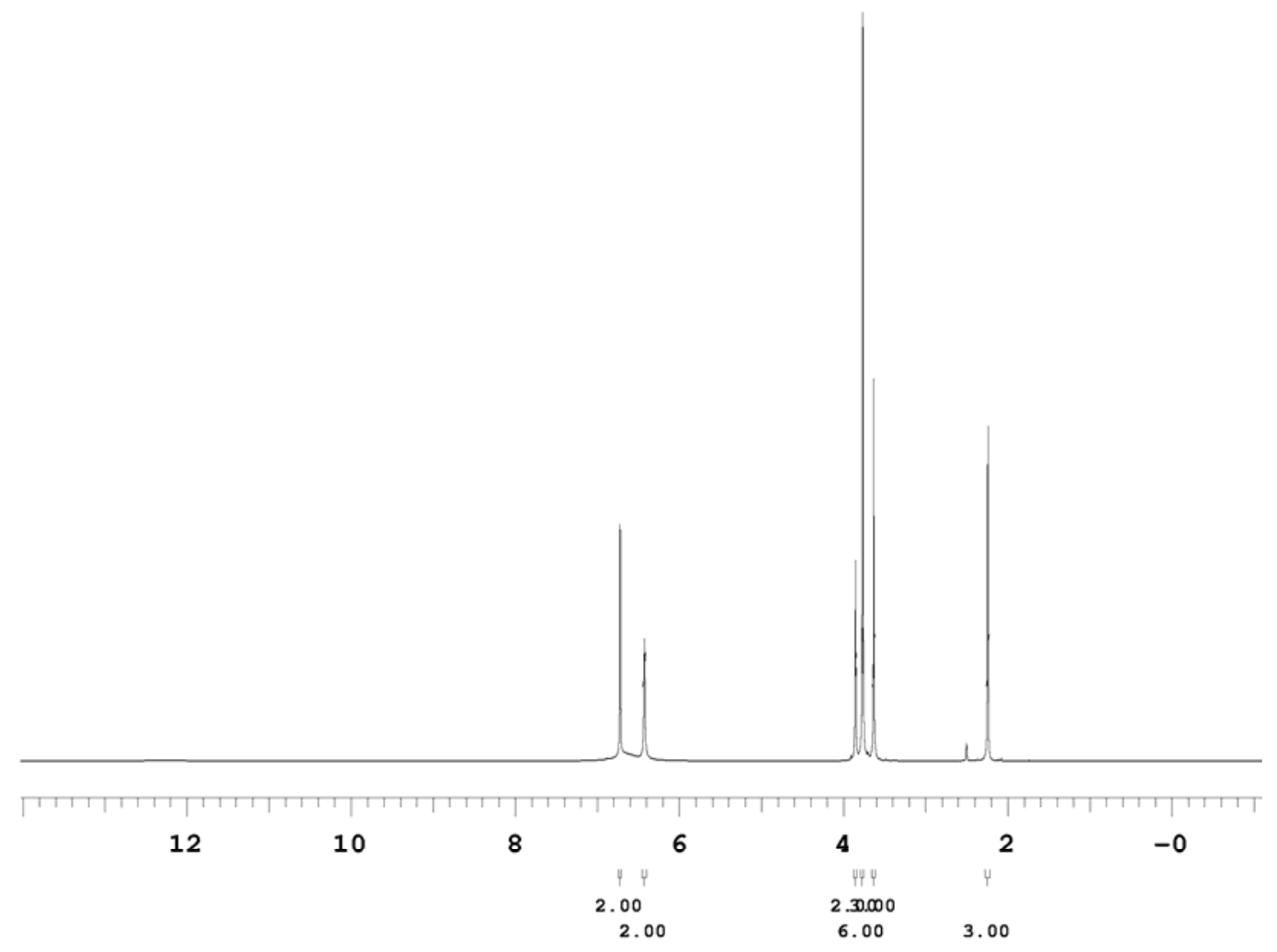


<smiles>COc1cc(CC#Cc2c(C)nc(N)nc2N)cc(OC)c1OC</smiles>

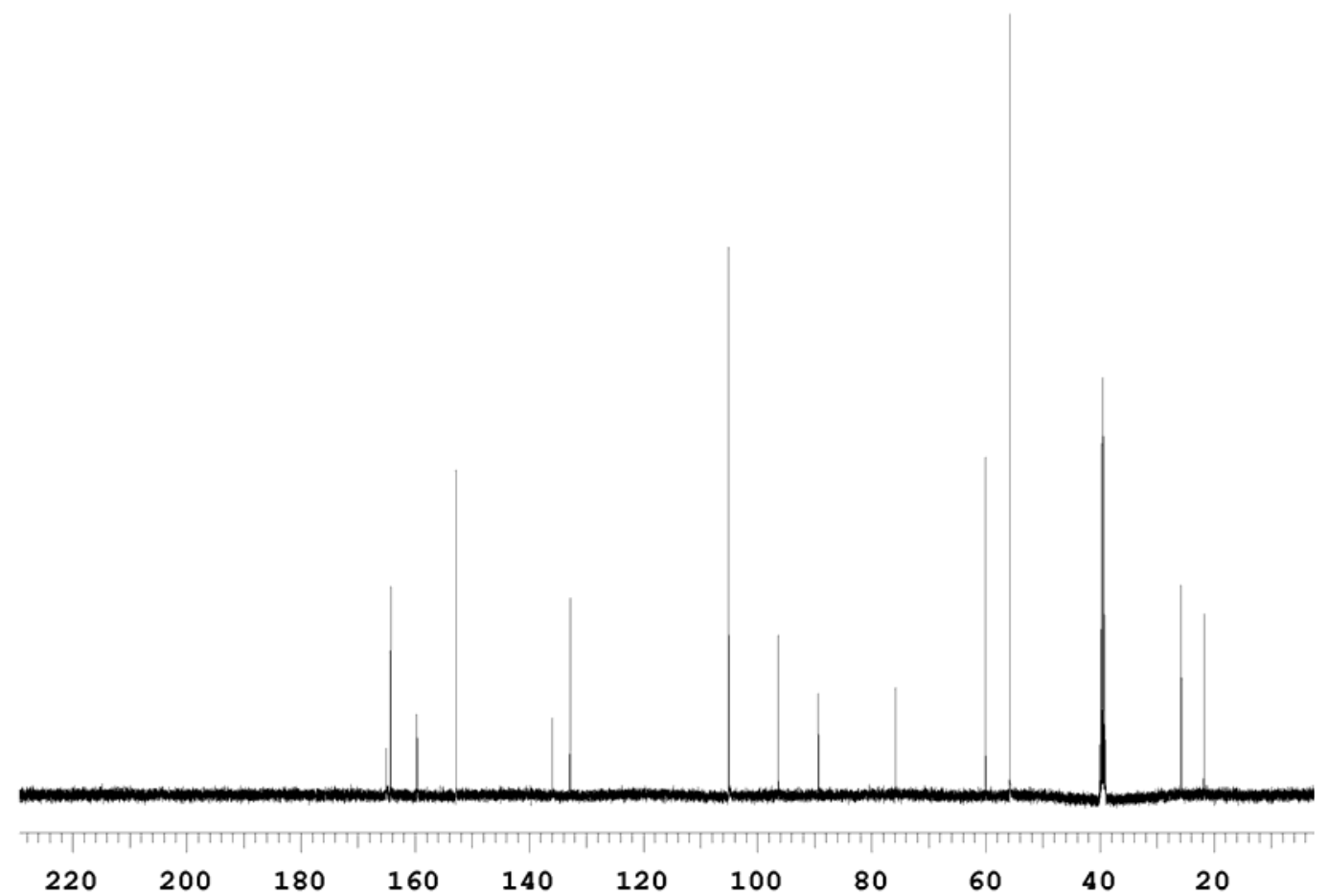



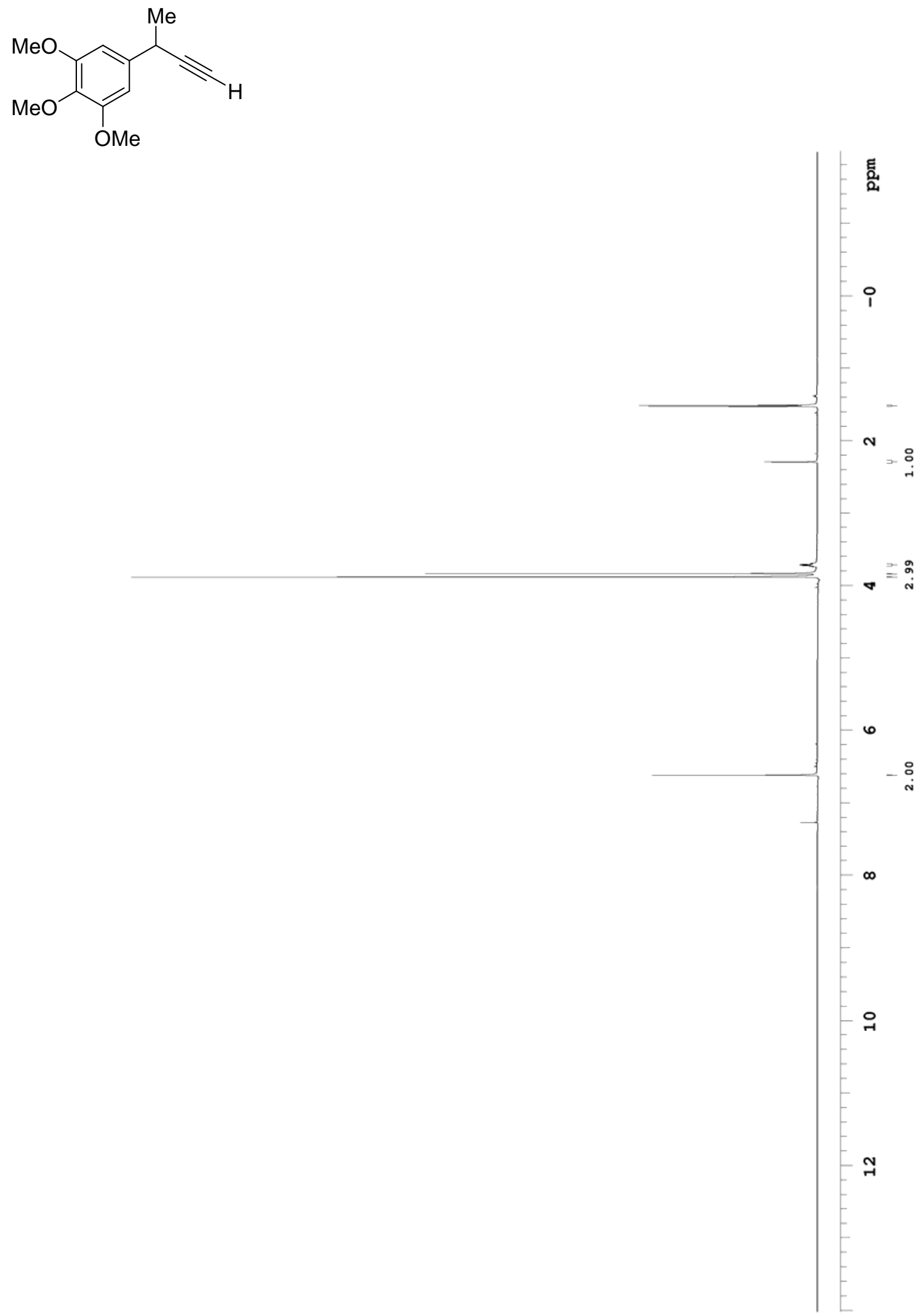

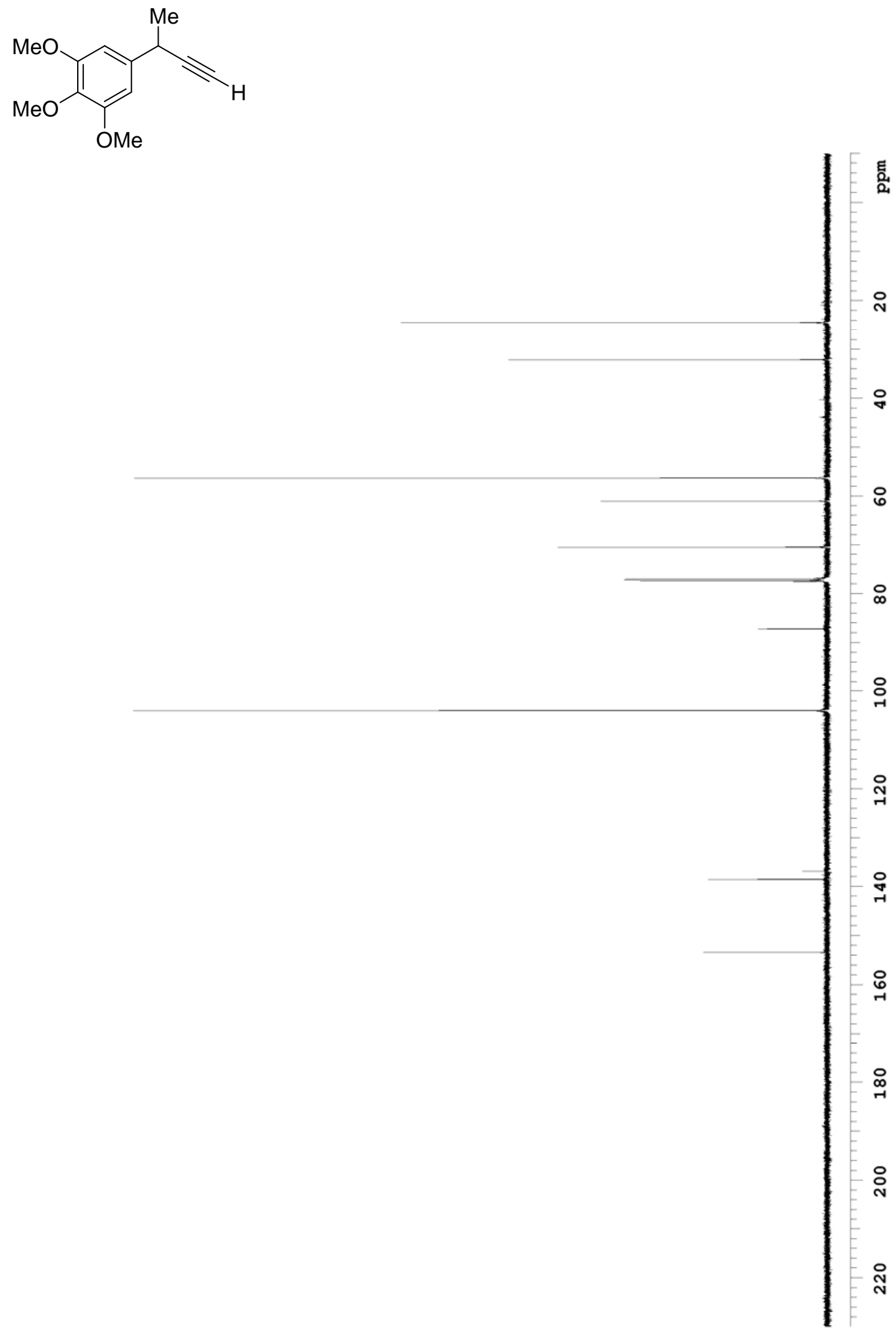
<smiles>COc1cc(C(C)C#Cc2cnc(N)nc2N)cc(OC)c1OC</smiles>

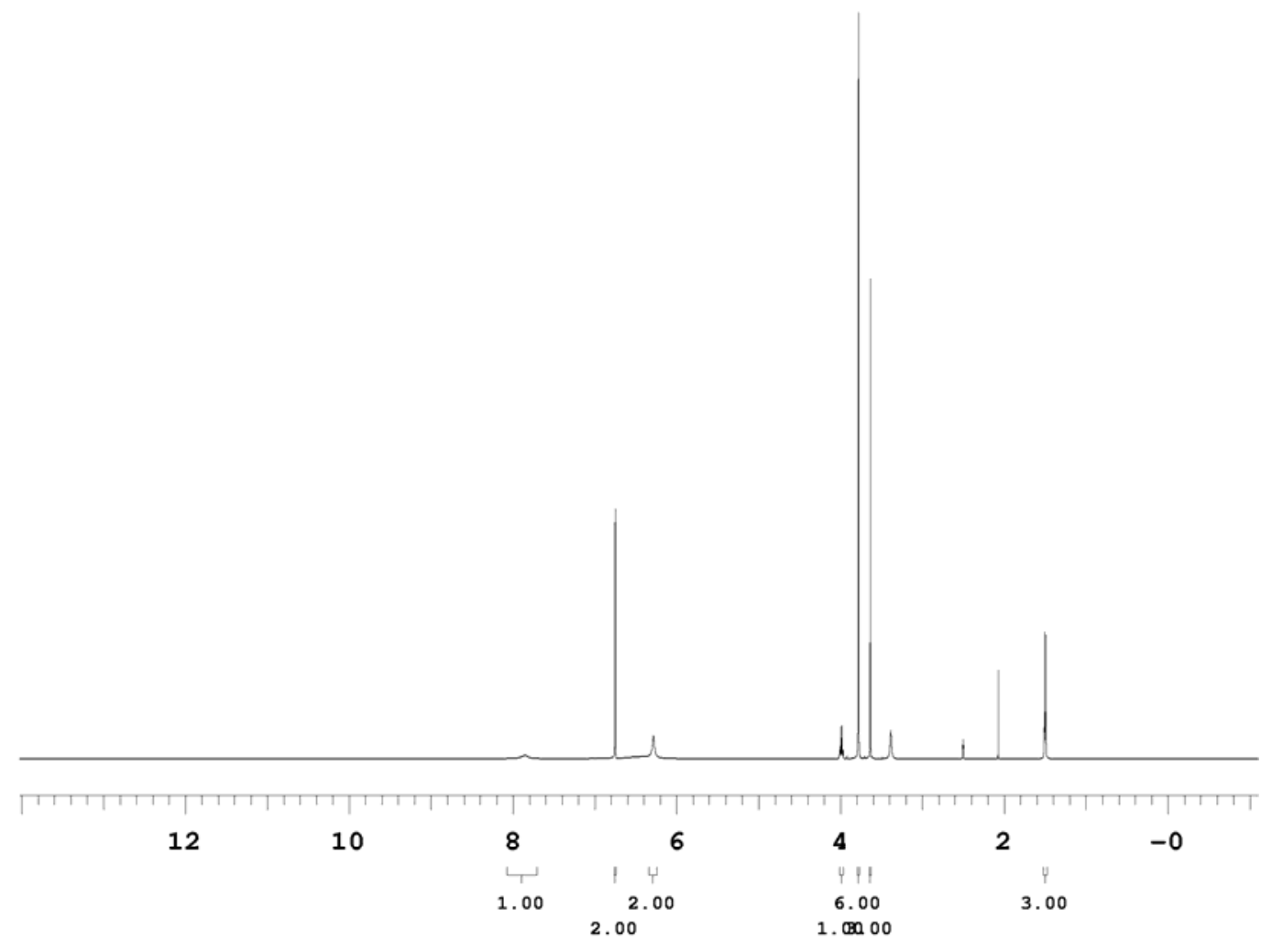


<smiles>COc1cc(C(C)C#Cc2cnc(N)nc2N)cc(OC)c1OC</smiles>

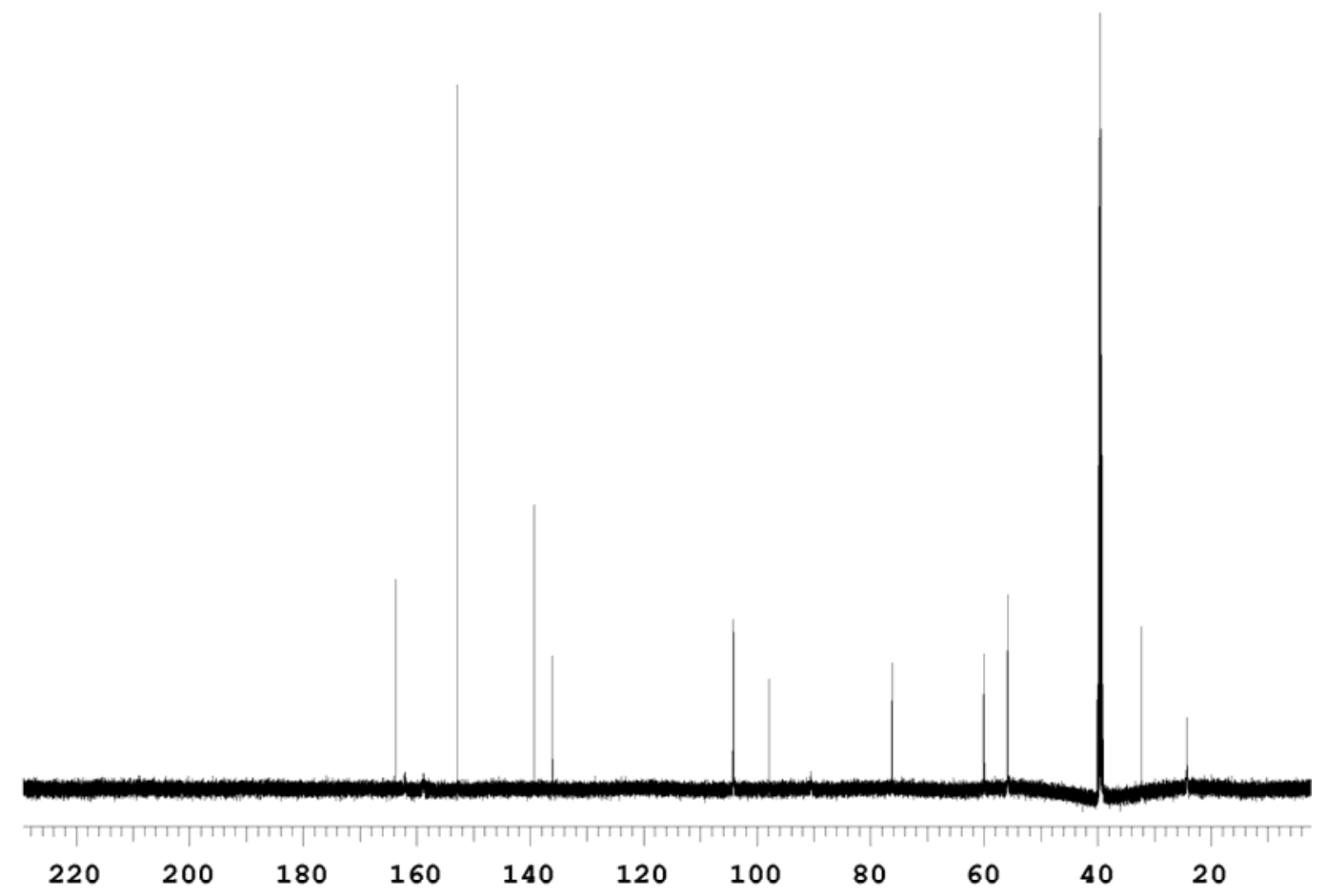


<smiles>COc1cc(C(C)C#Cc2c(C)nc(N)nc2N)cc(OC)c1OC</smiles>

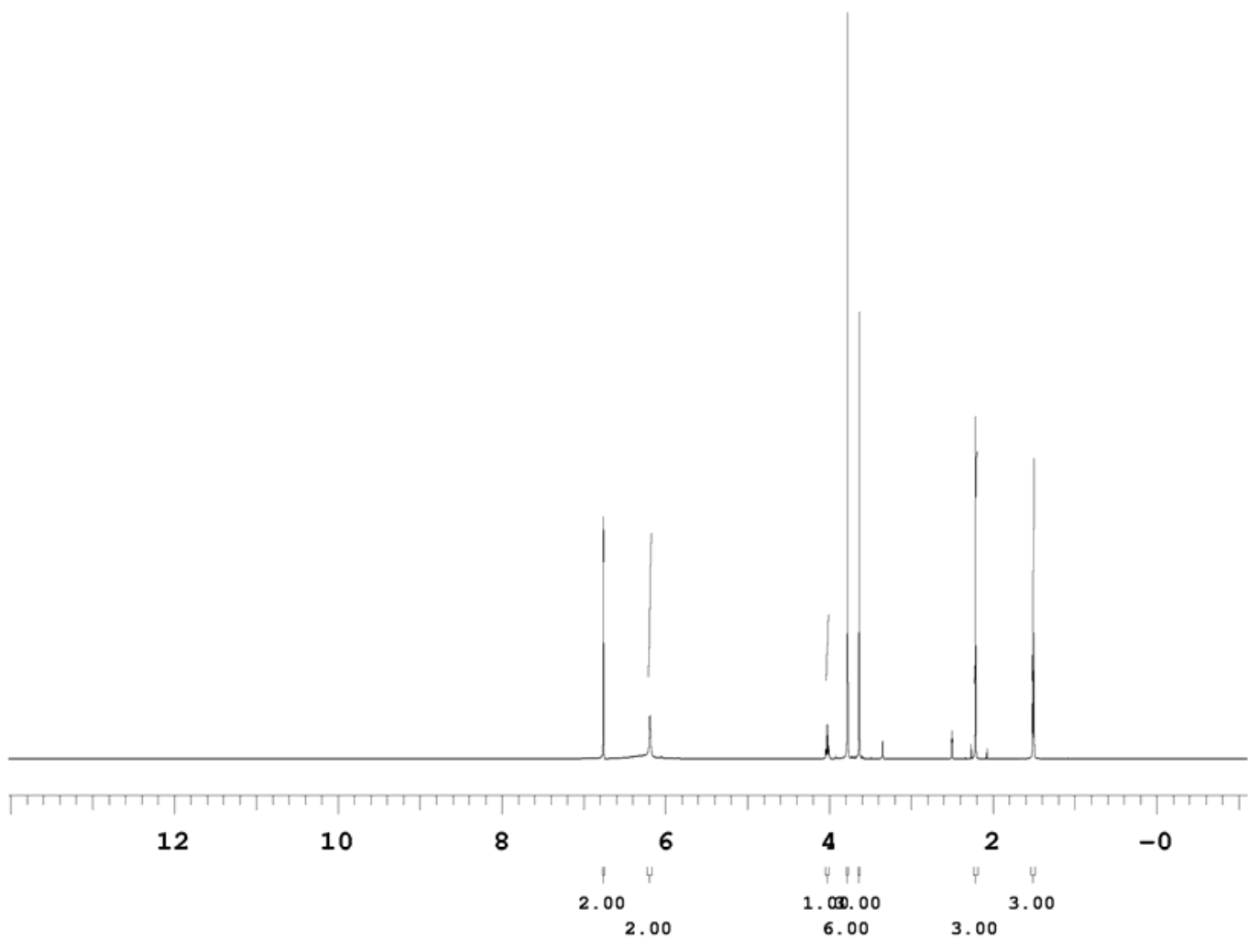


<smiles>COc1cc(C(C)C#Cc2c(C)nc(N)nc2N)cc(OC)c1OC</smiles>

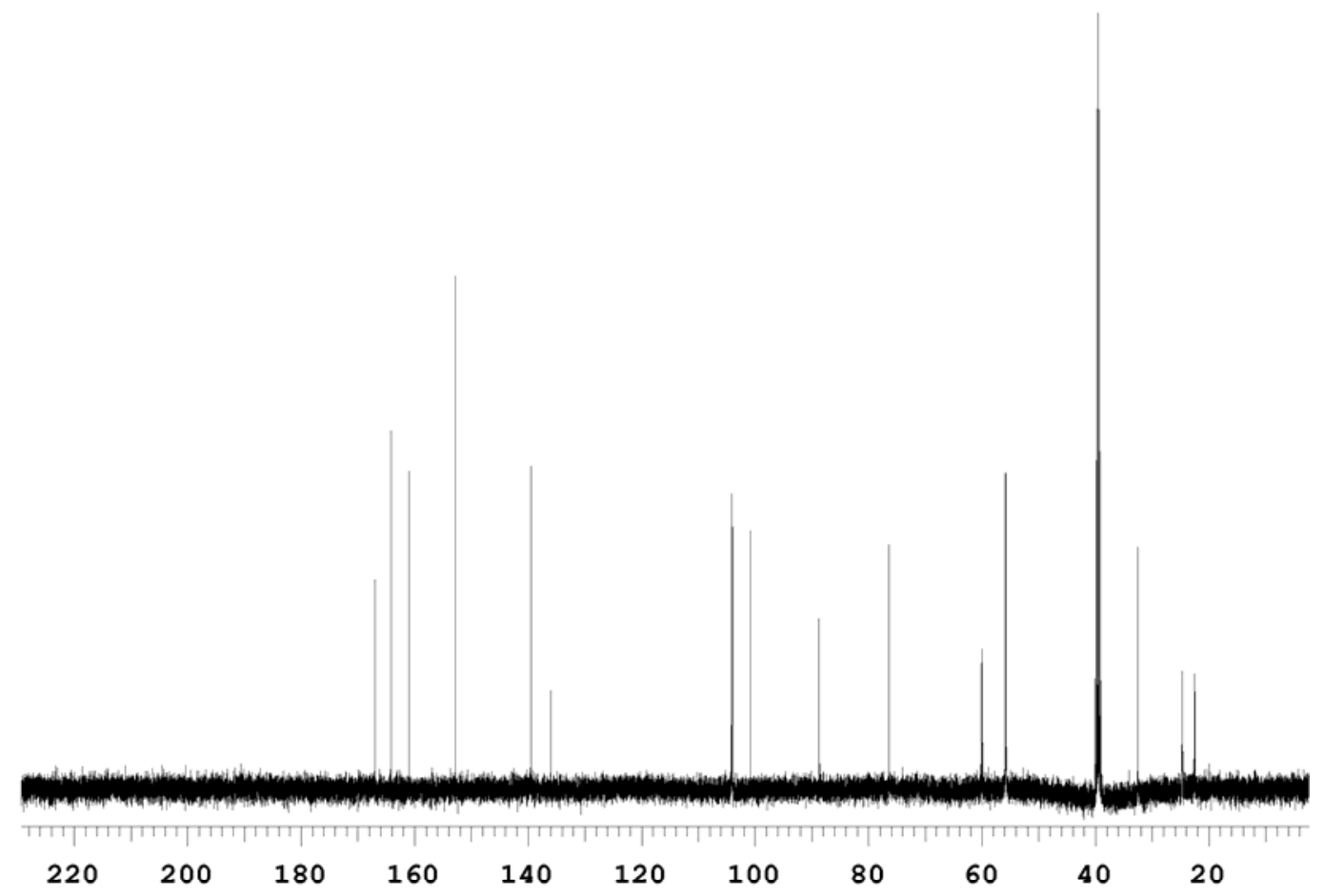



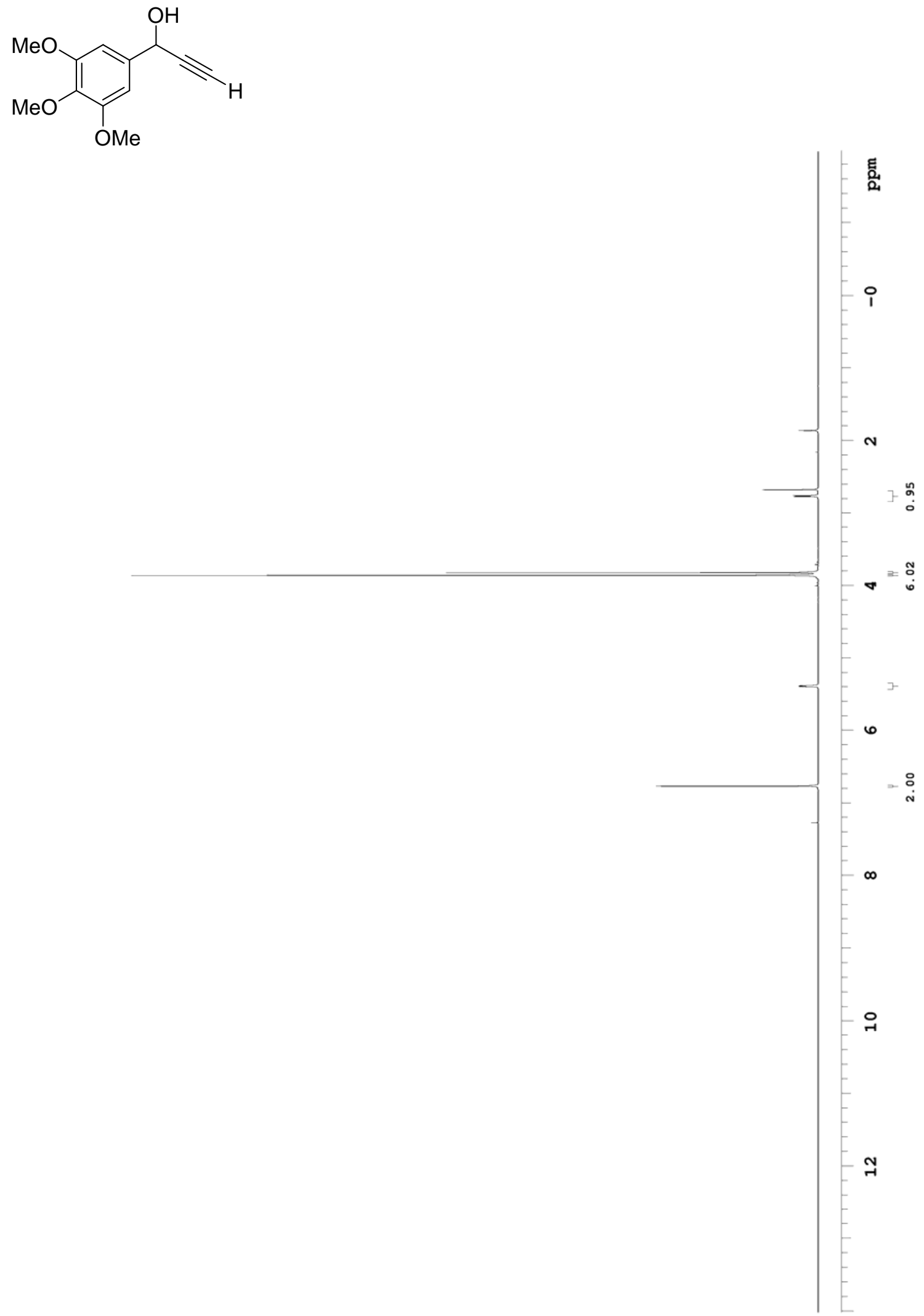

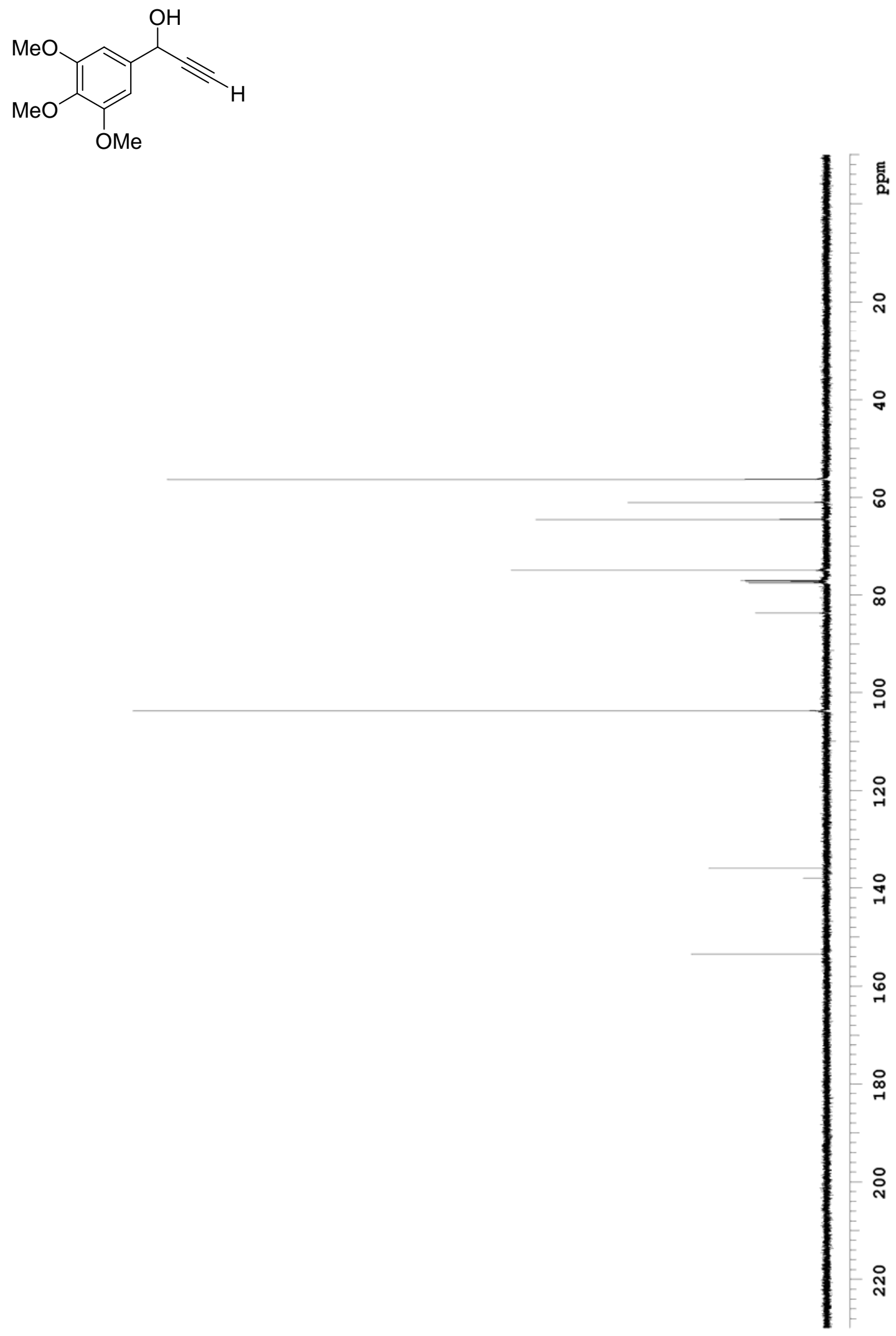
<smiles>COc1cc(C(O)C#Cc2cnc(N)nc2N)cc(OC)c1OC</smiles>

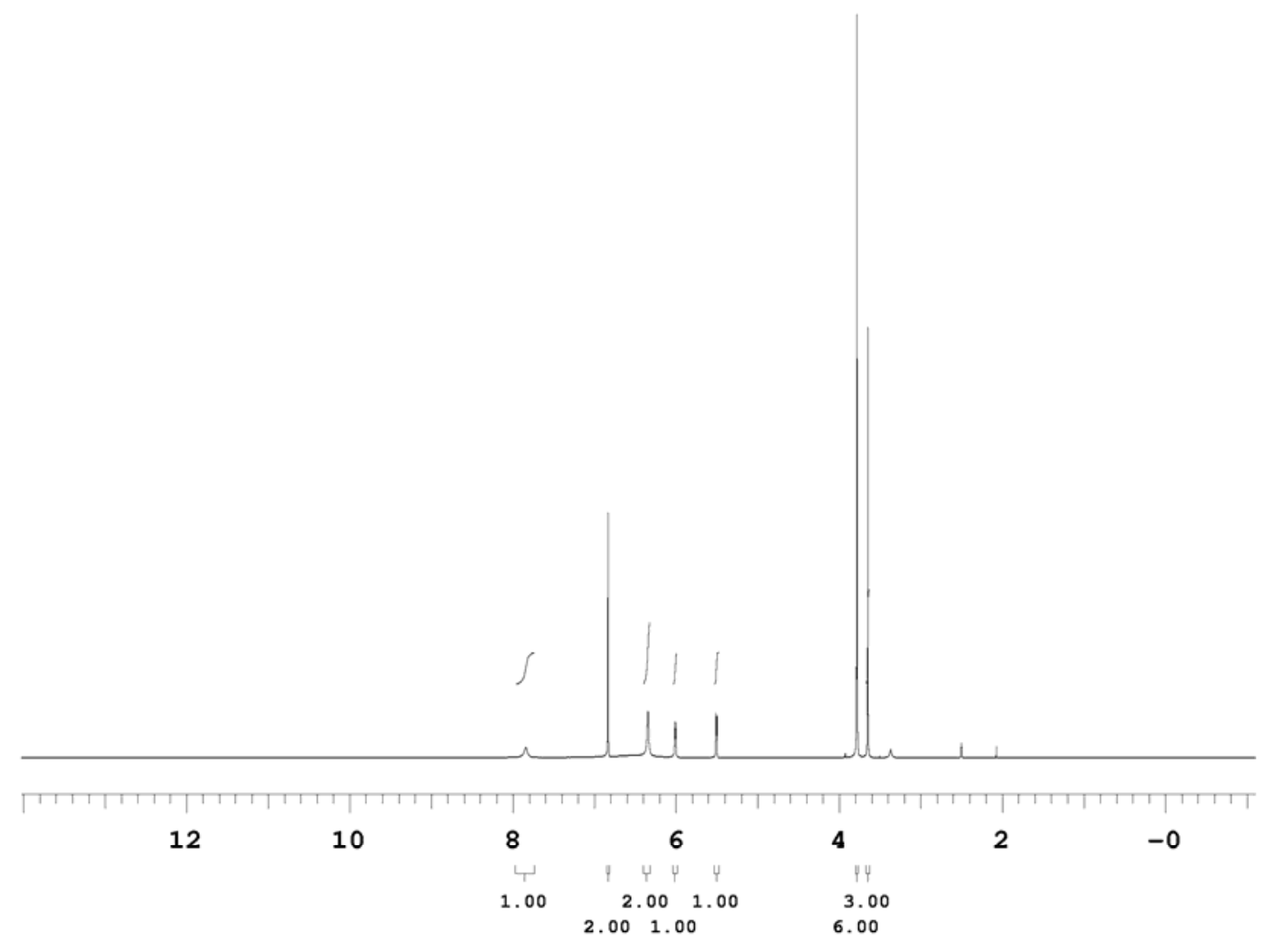


<smiles>COc1cc(C(O)C#Cc2cnc(N)nc2N)cc(OC)c1OC</smiles>

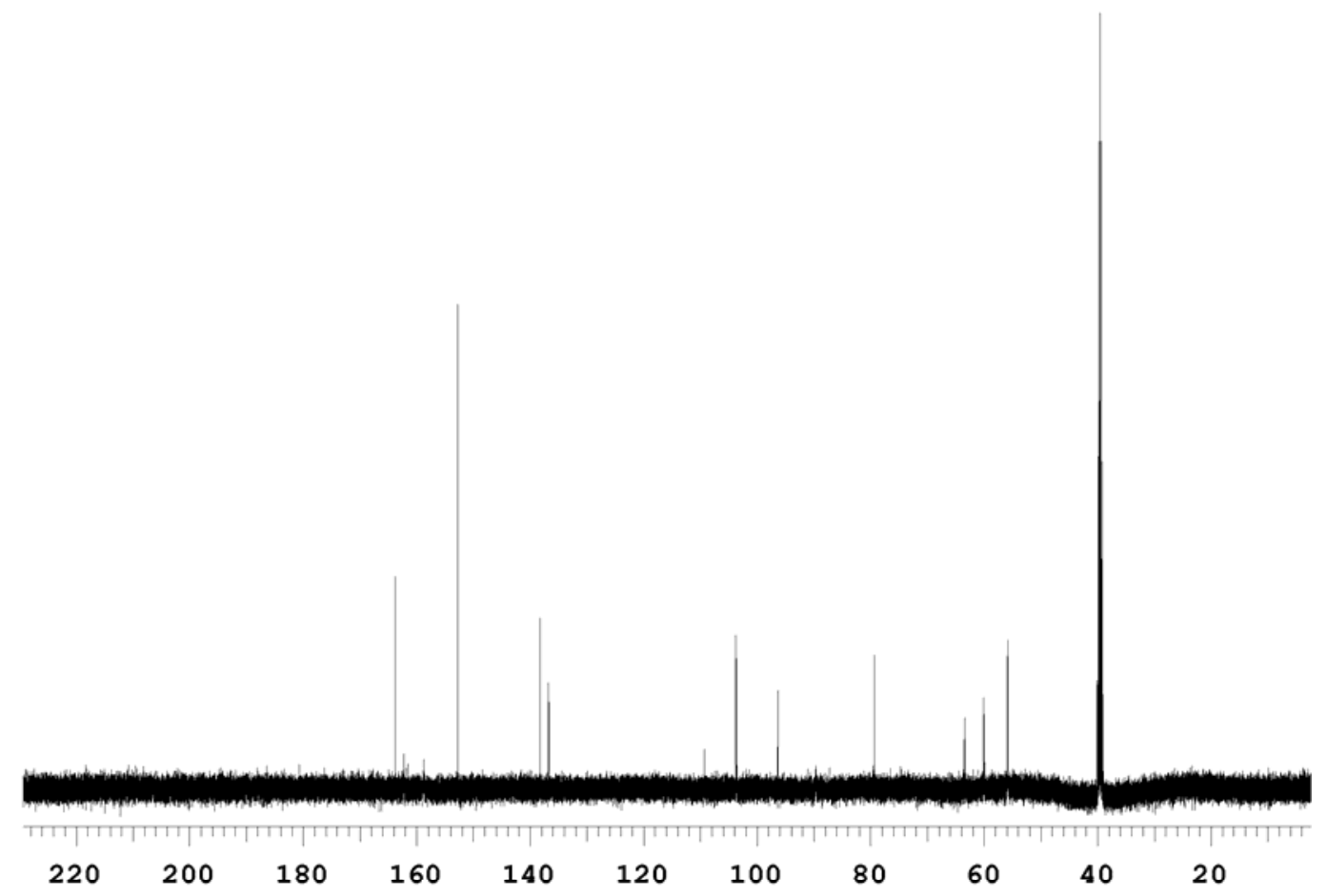


<smiles>COc1cc(C(O)C#Cc2c(C)nc(N)nc2N)cc(OC)c1OC</smiles>

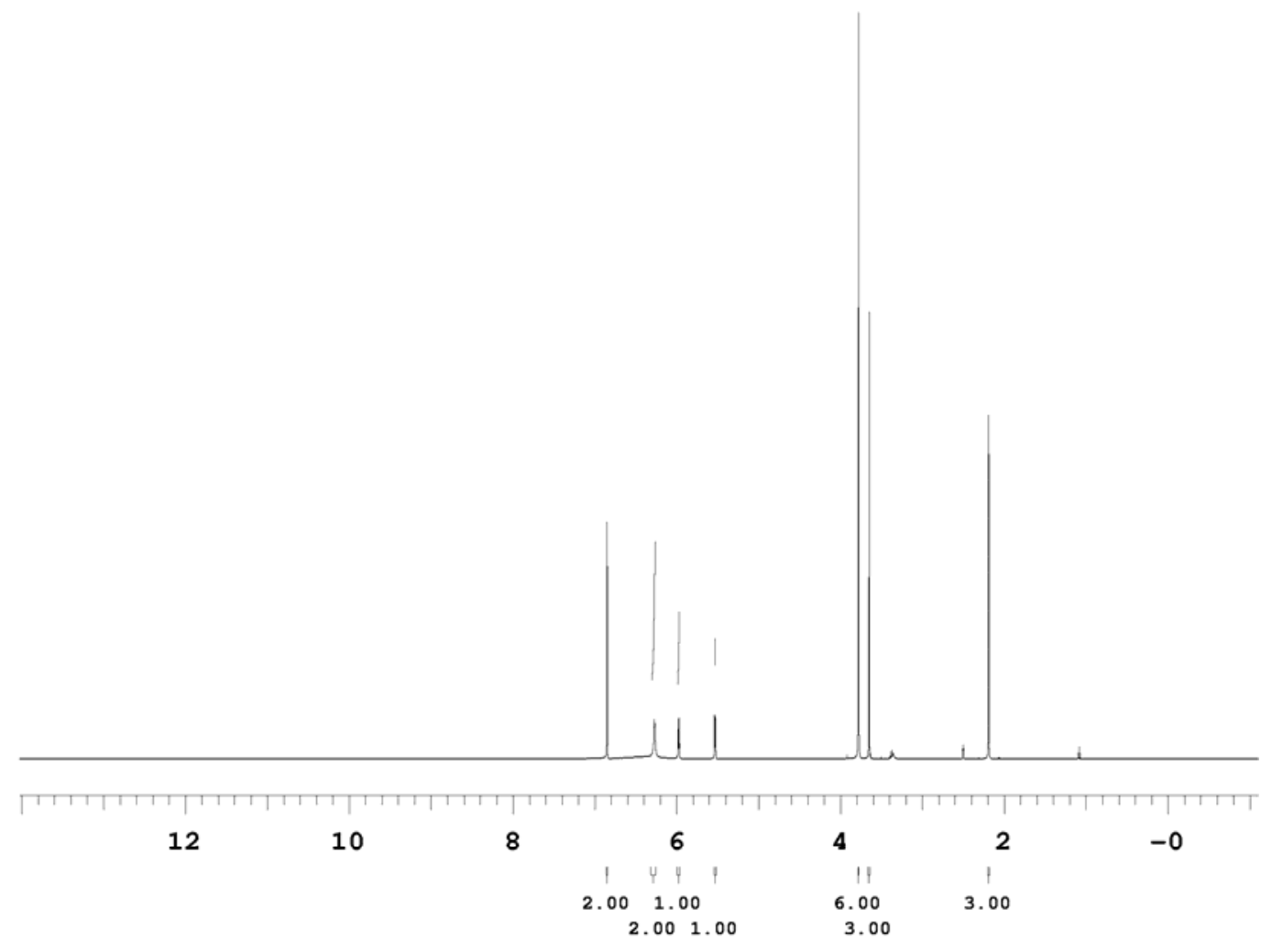


<smiles>COc1cc(C(O)C#Cc2c(C)nc(N)nc2N)cc(OC)c1OC</smiles>

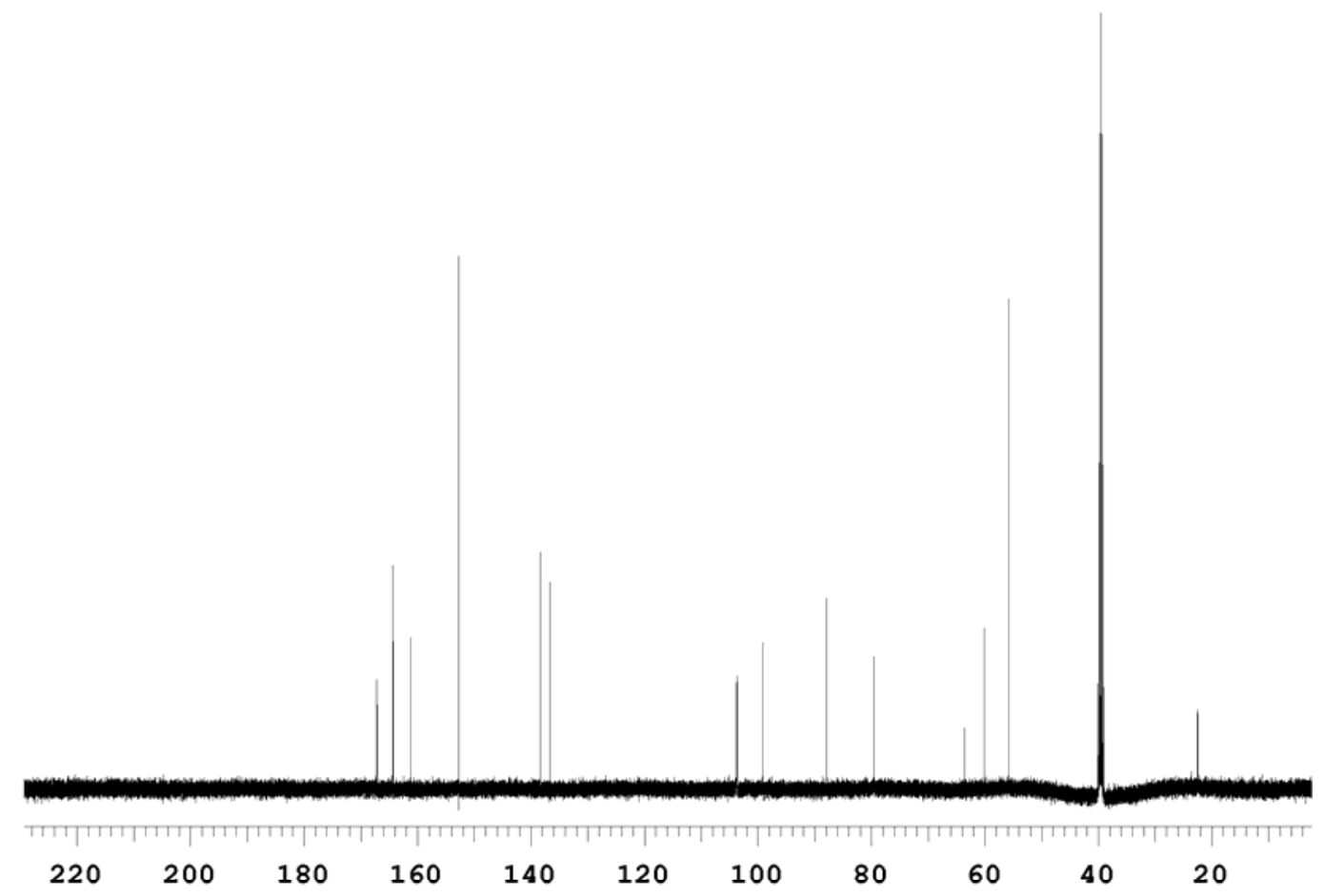



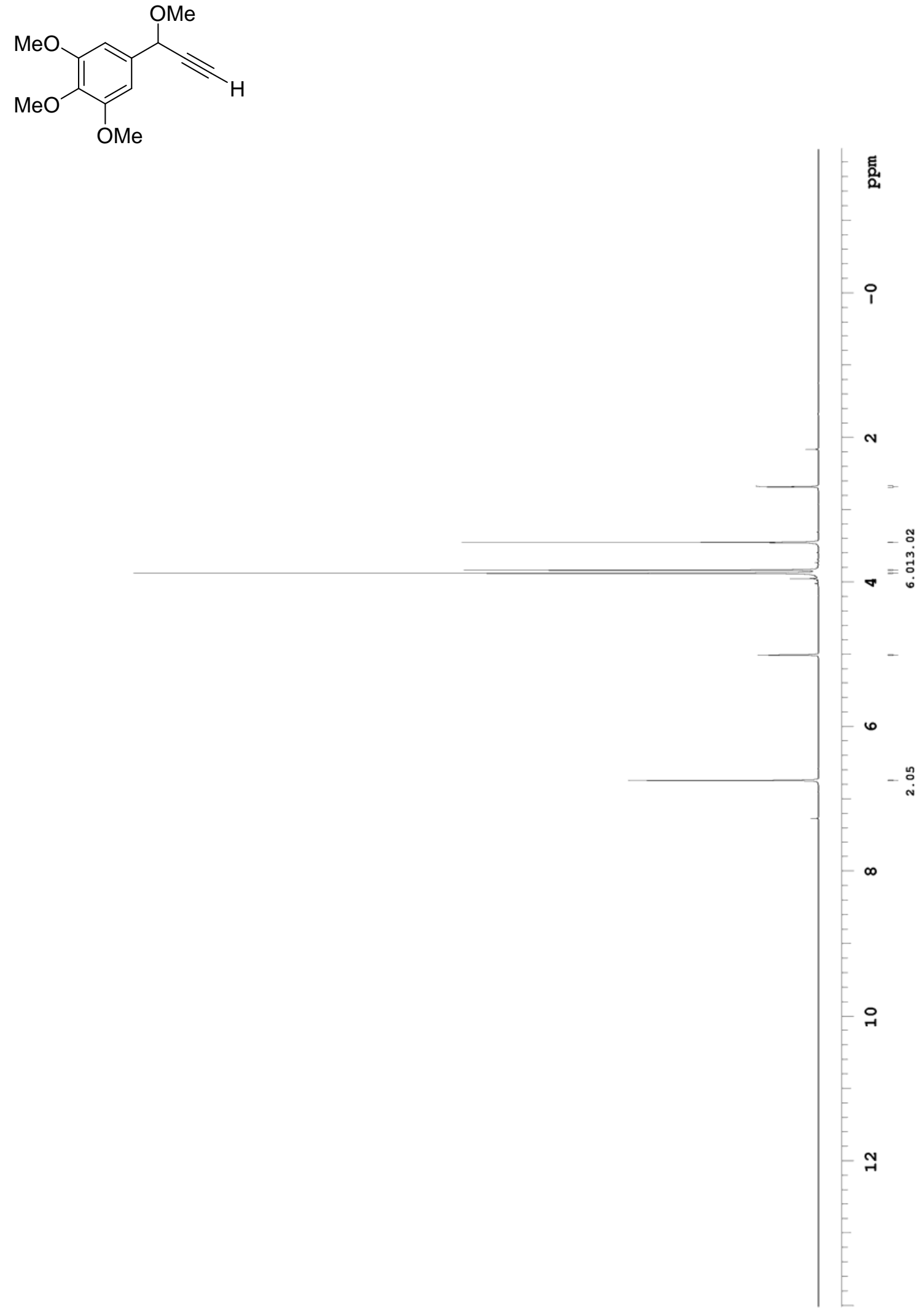

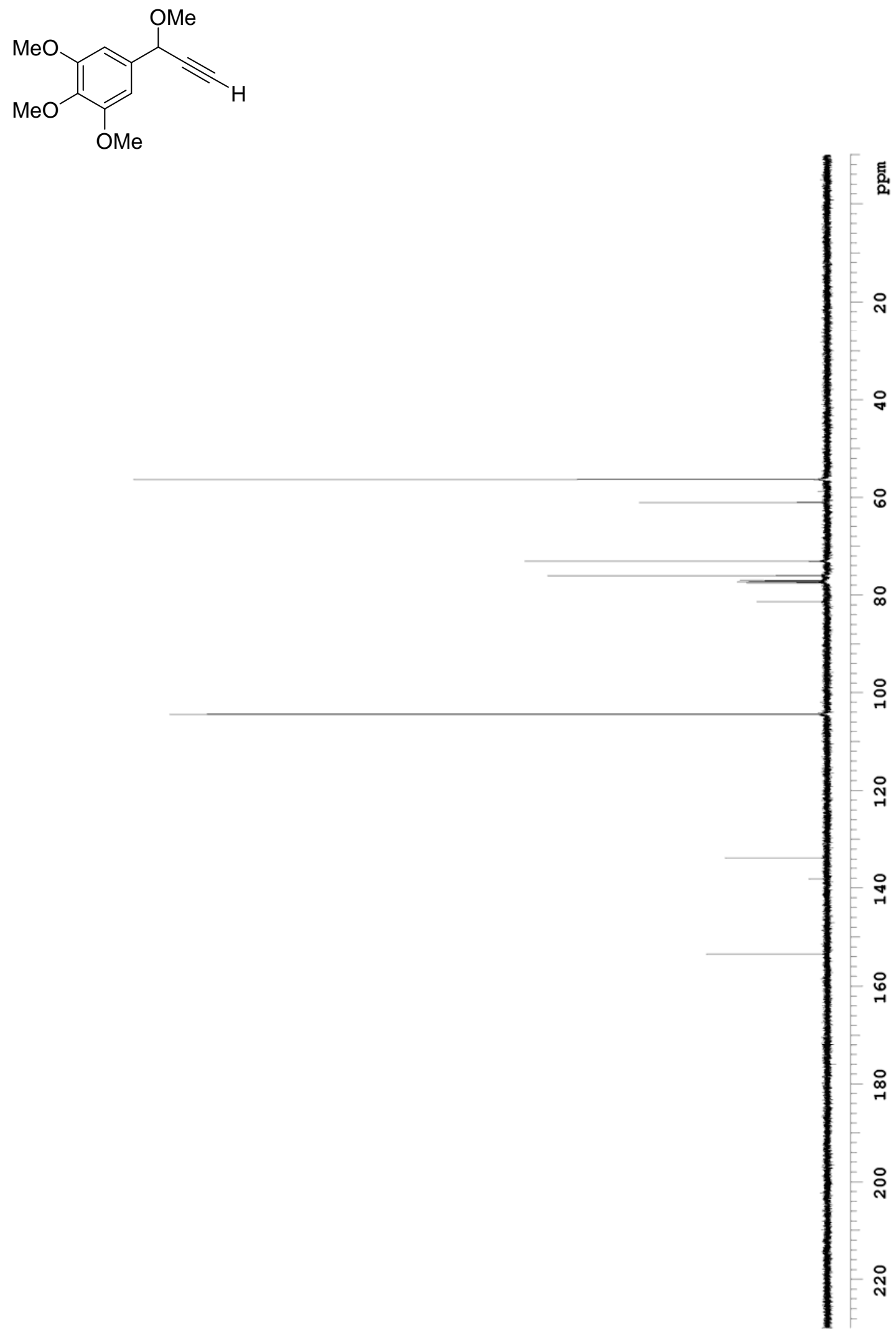
<smiles>COc1cc(C(C#Cc2cnc(N)nc2N)OC)cc(OC)c1OC</smiles>

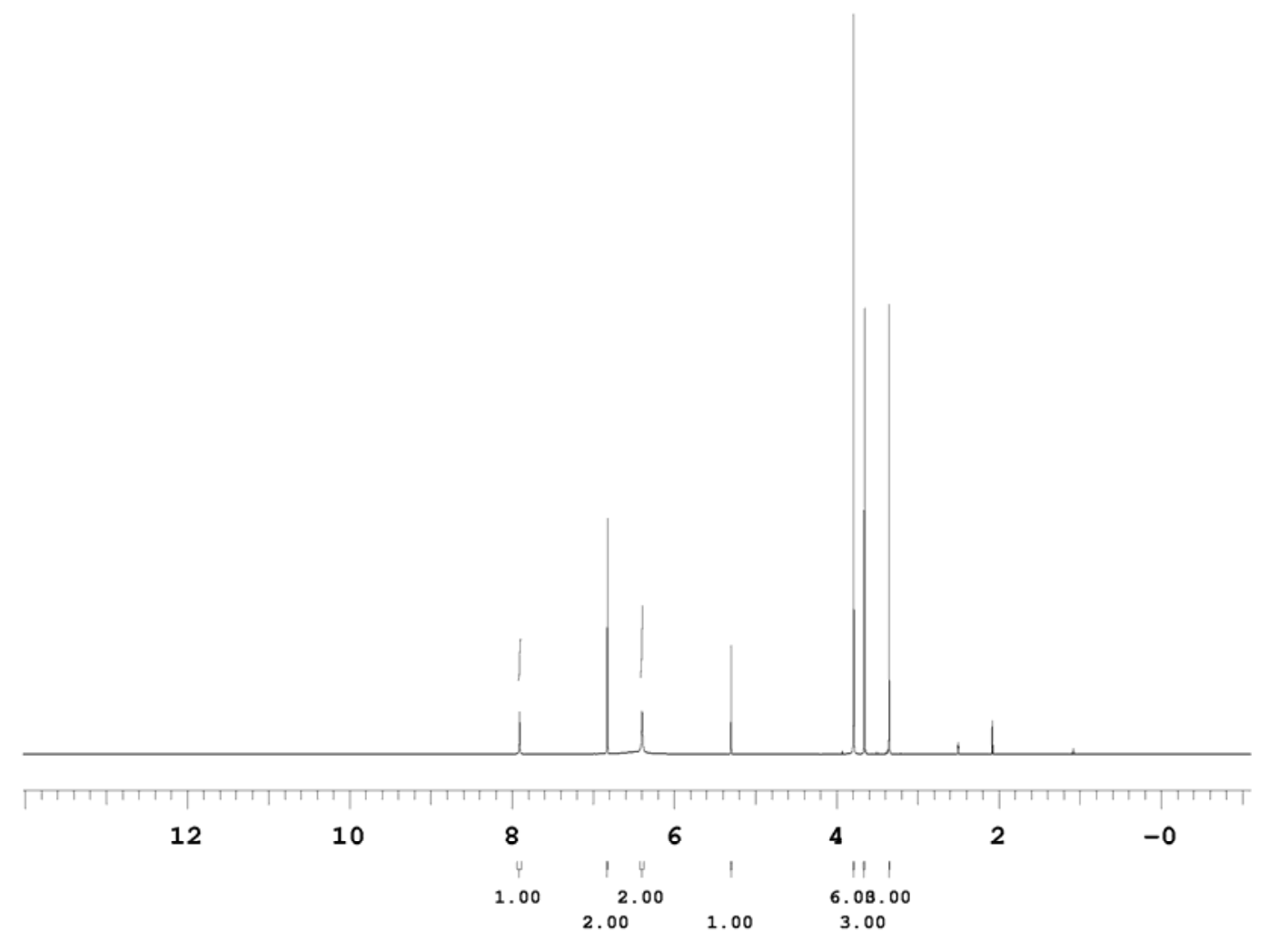


<smiles>COc1cc(C(C#Cc2cnc(N)nc2N)OC)cc(OC)c1OC</smiles>

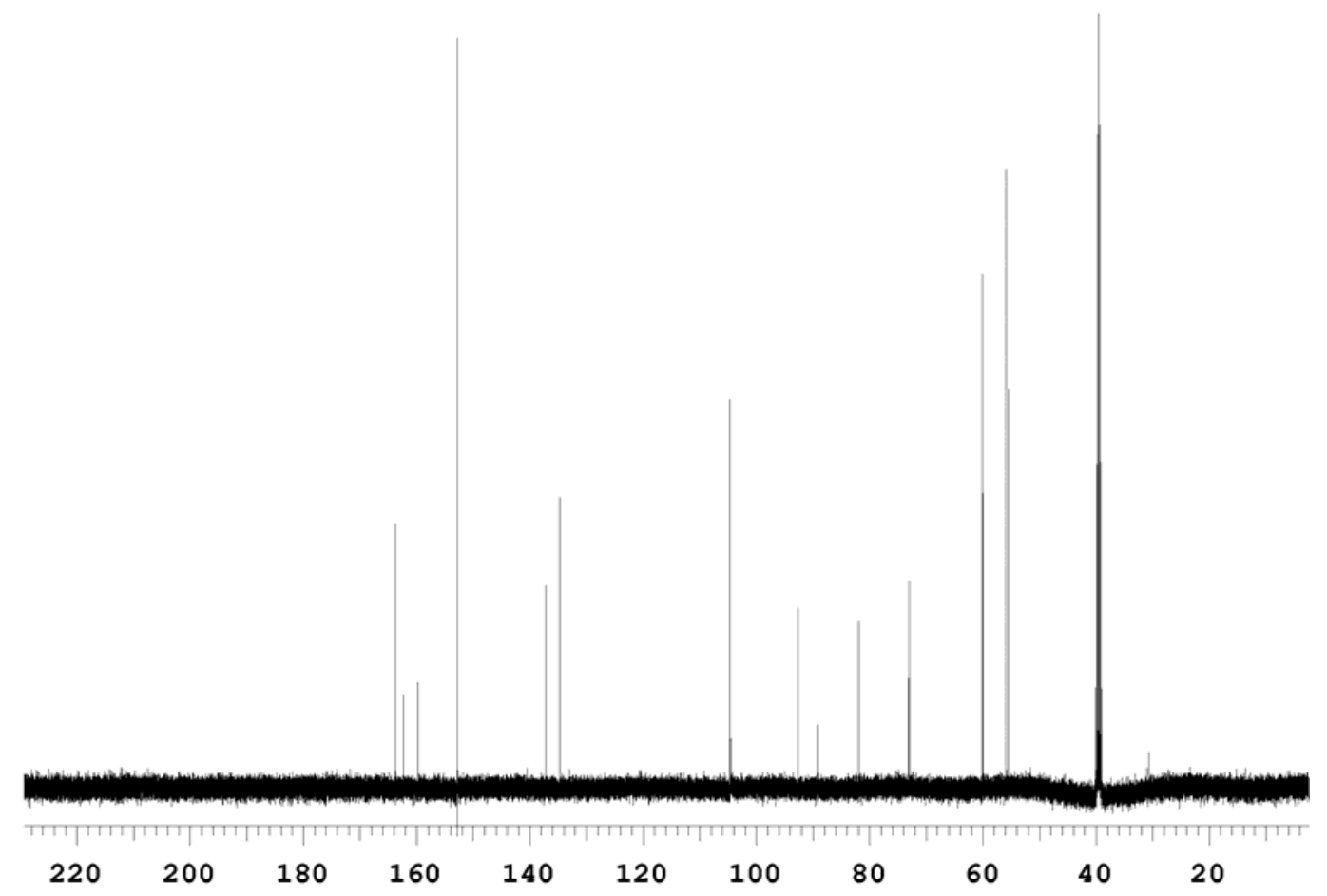


<smiles>COc1cc(C(C#Cc2c(C)nc(N)nc2N)OC)cc(OC)c1OC</smiles>

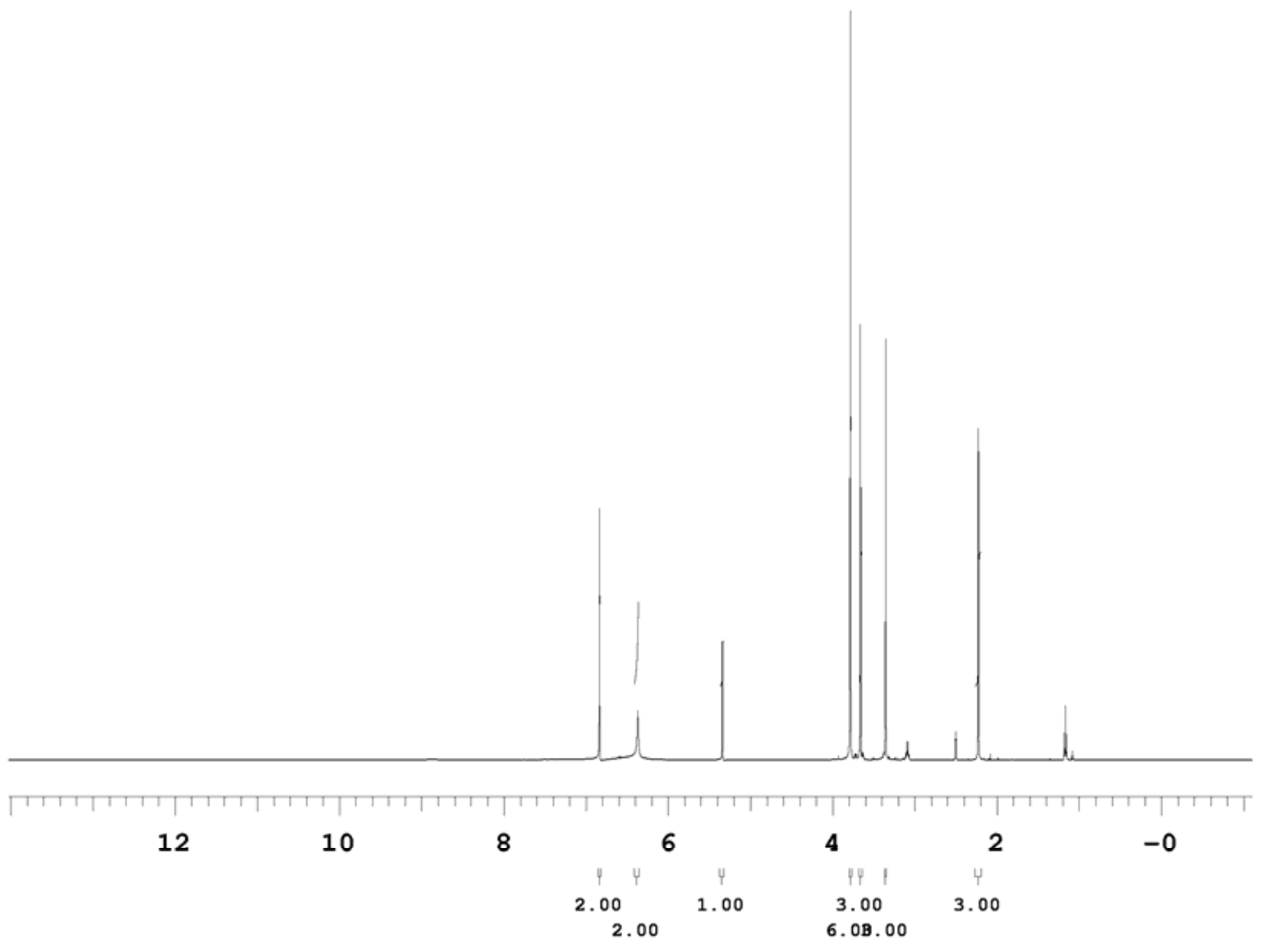


<smiles>COc1cc(C(C#Cc2c(C)nc(N)nc2N)OC)cc(OC)c1OC</smiles>

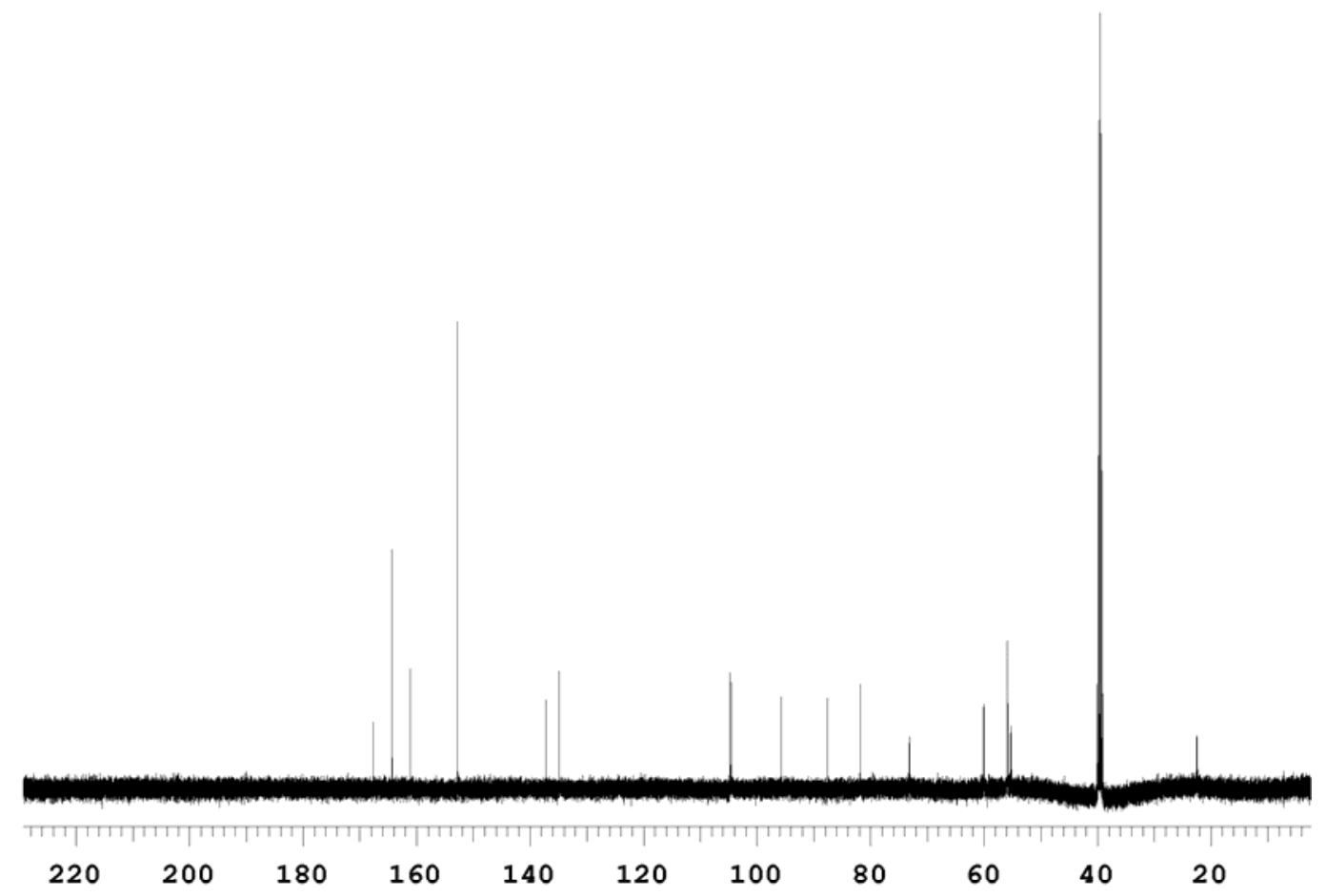



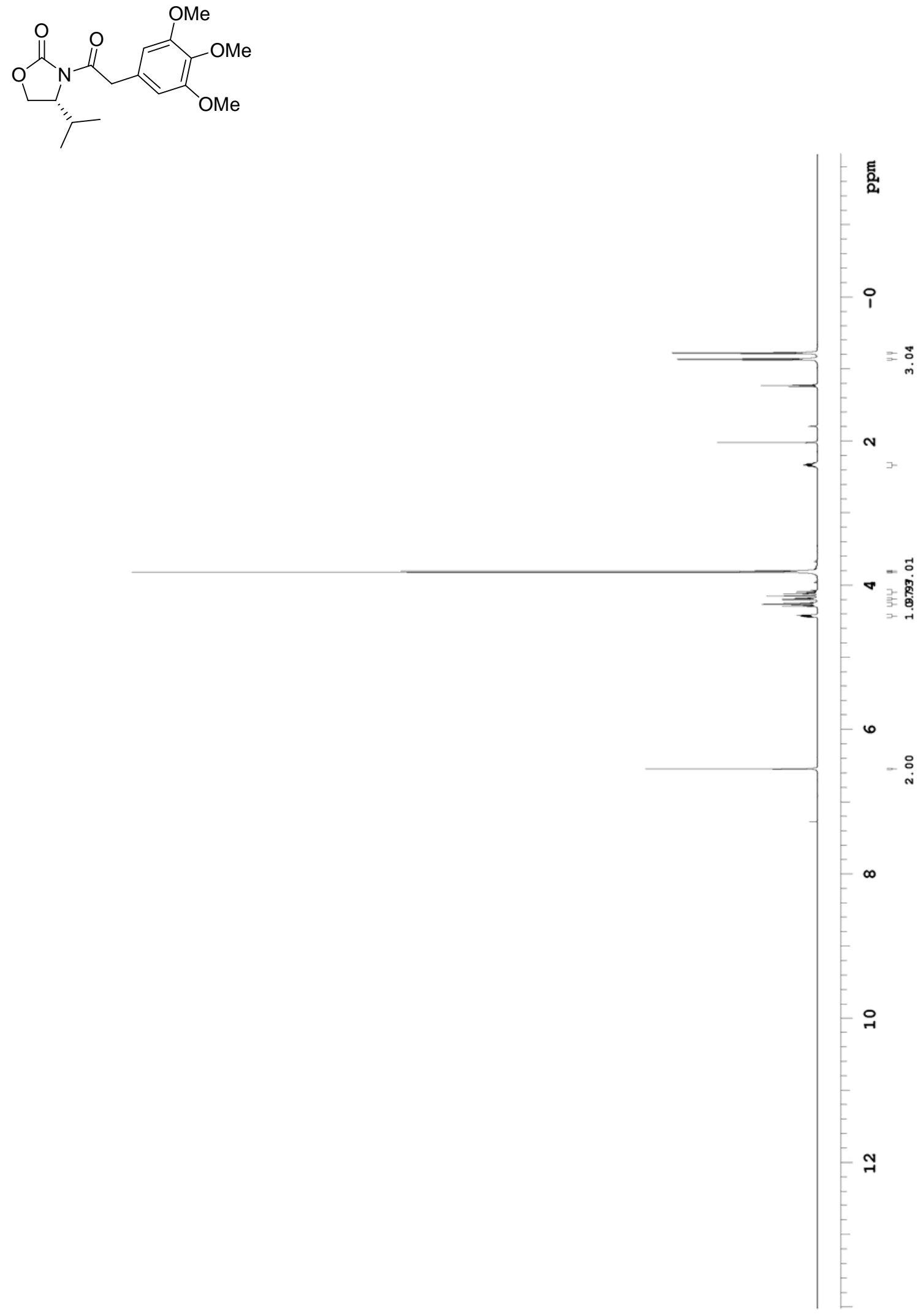

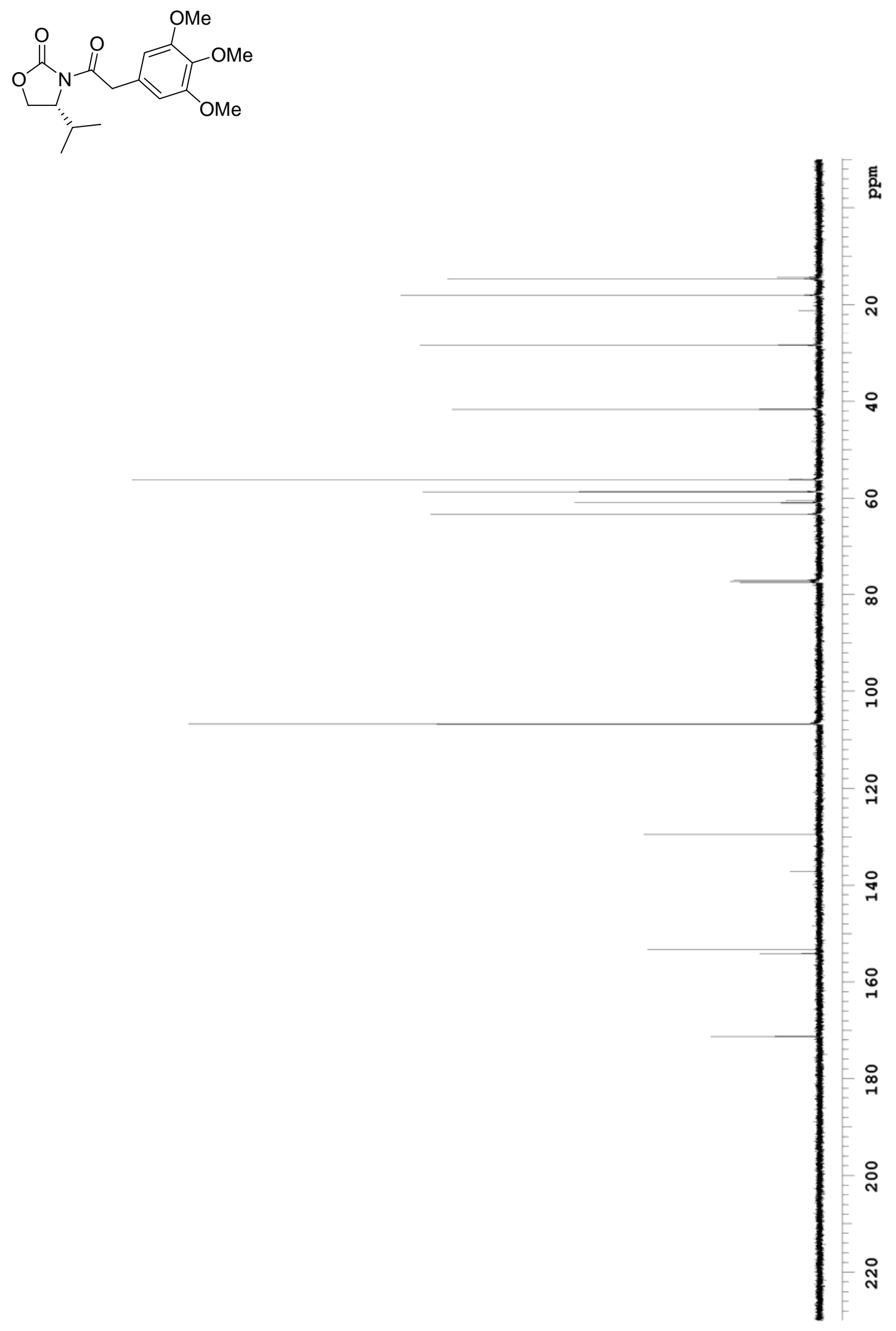

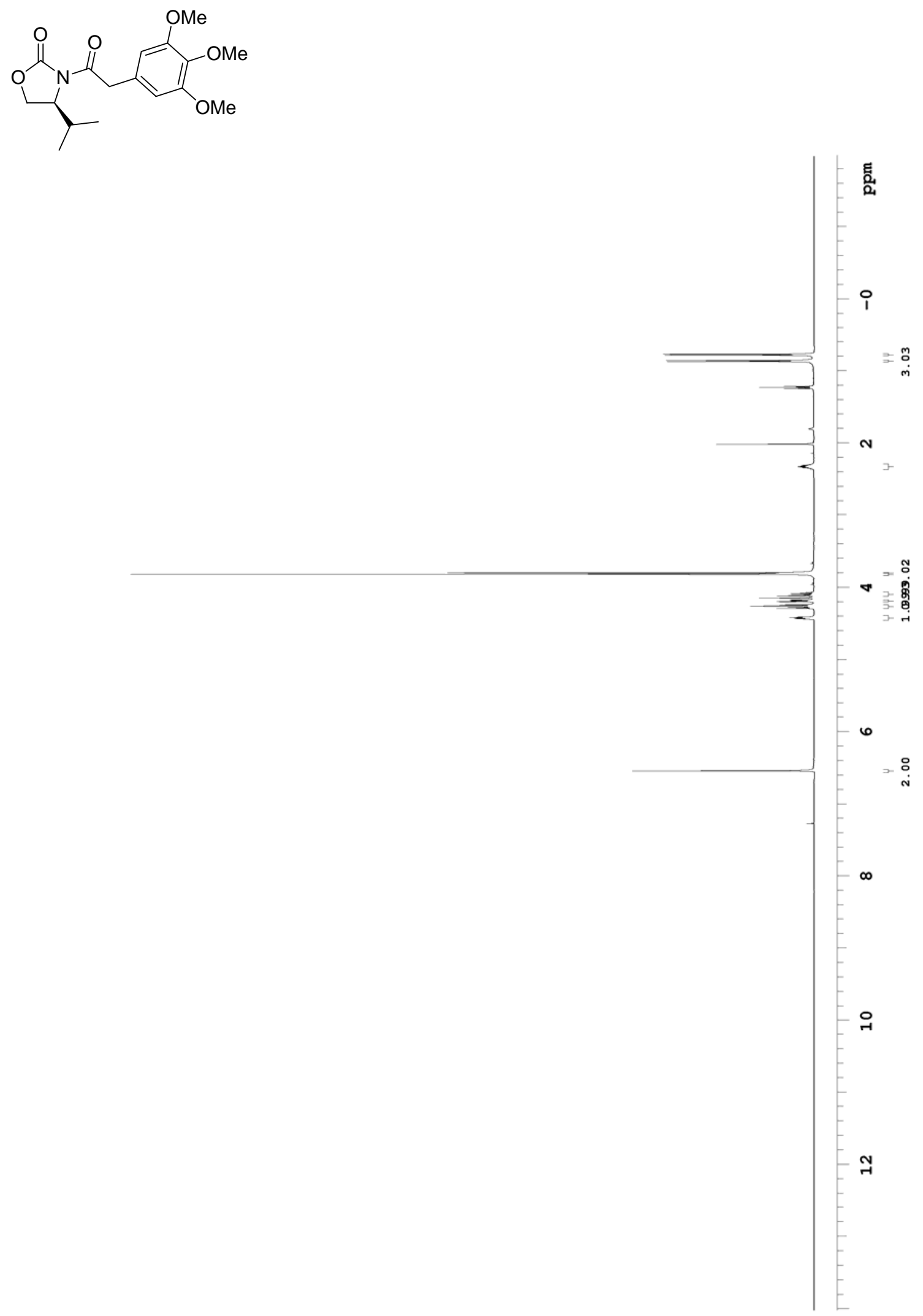

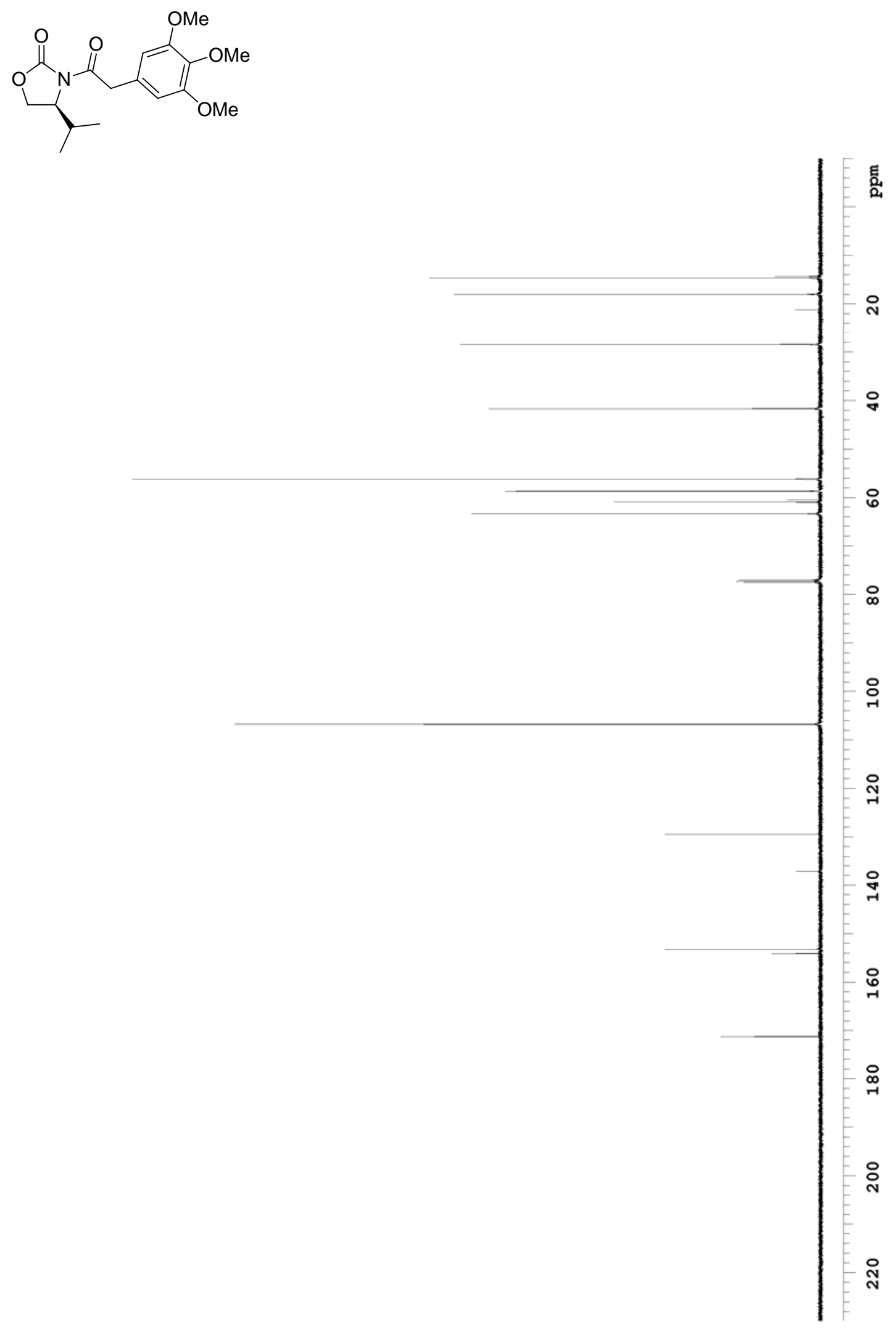

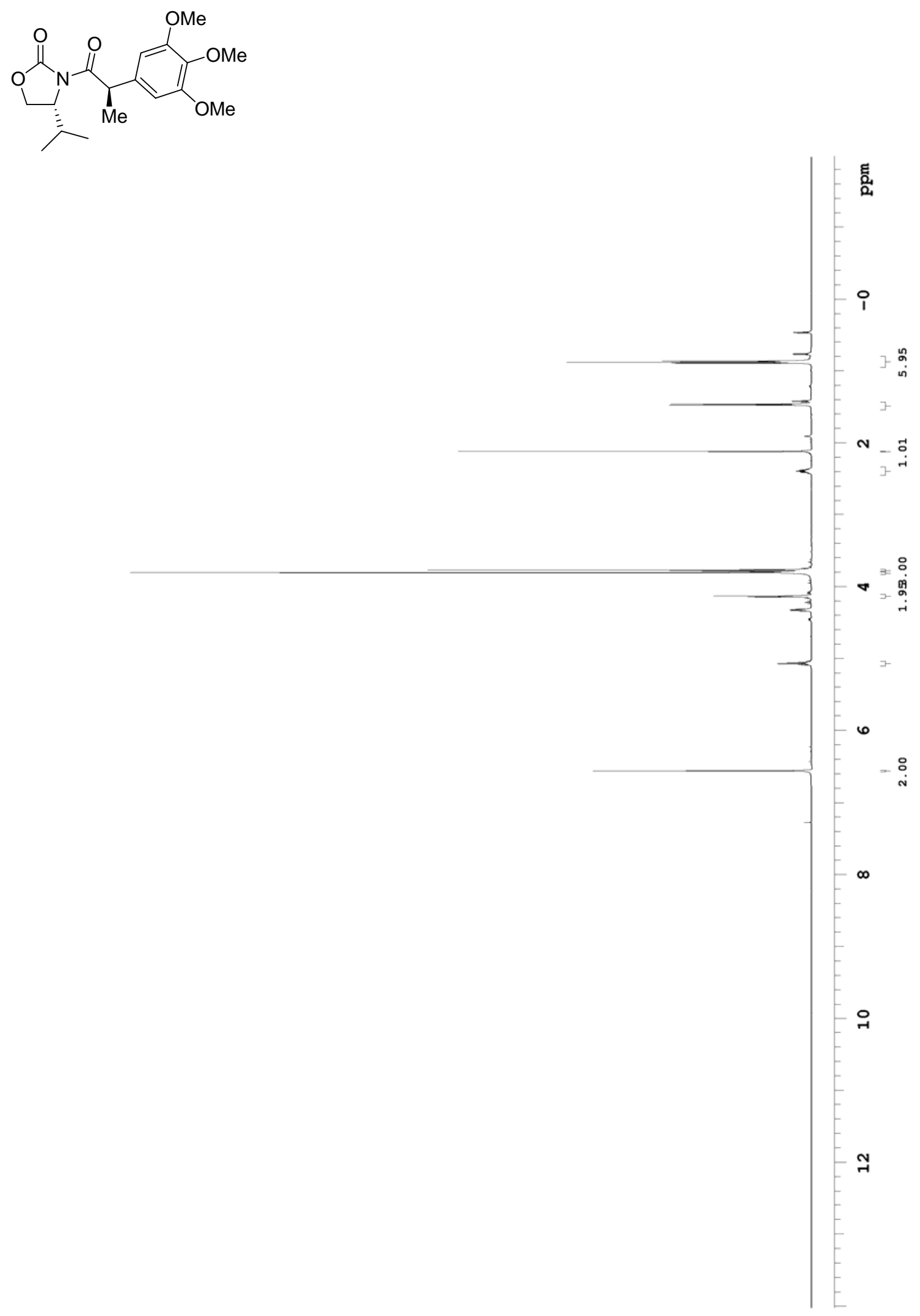

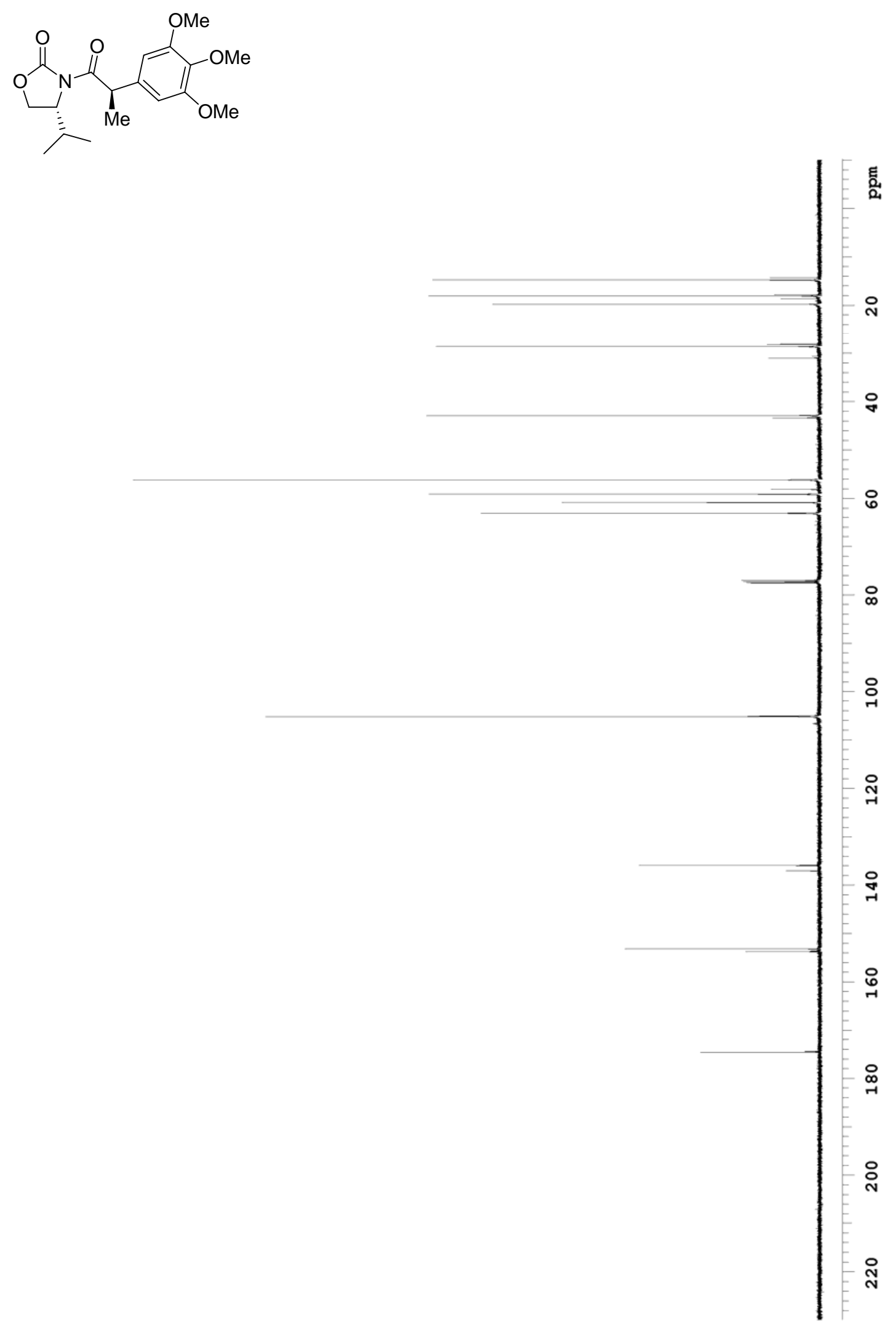

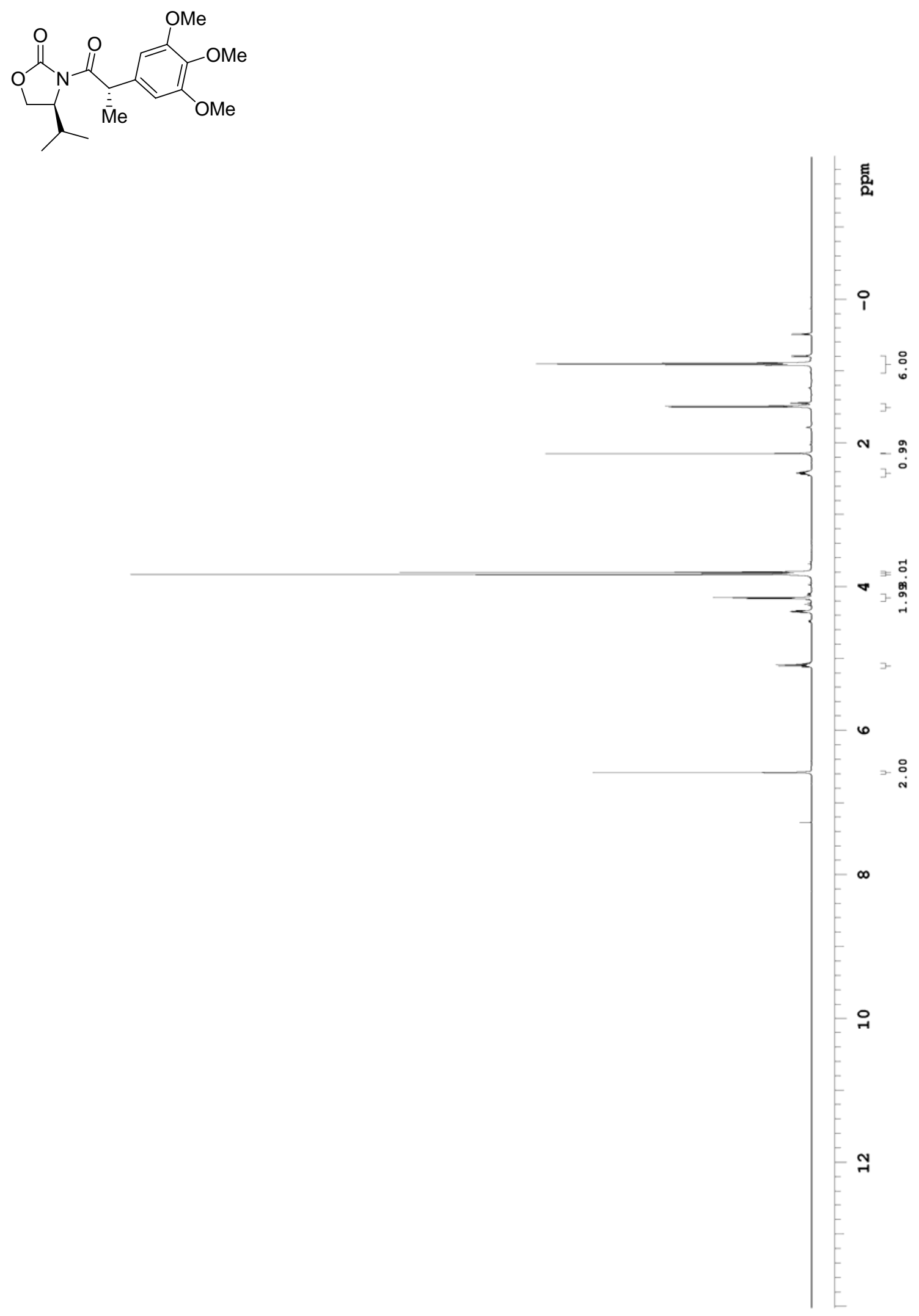

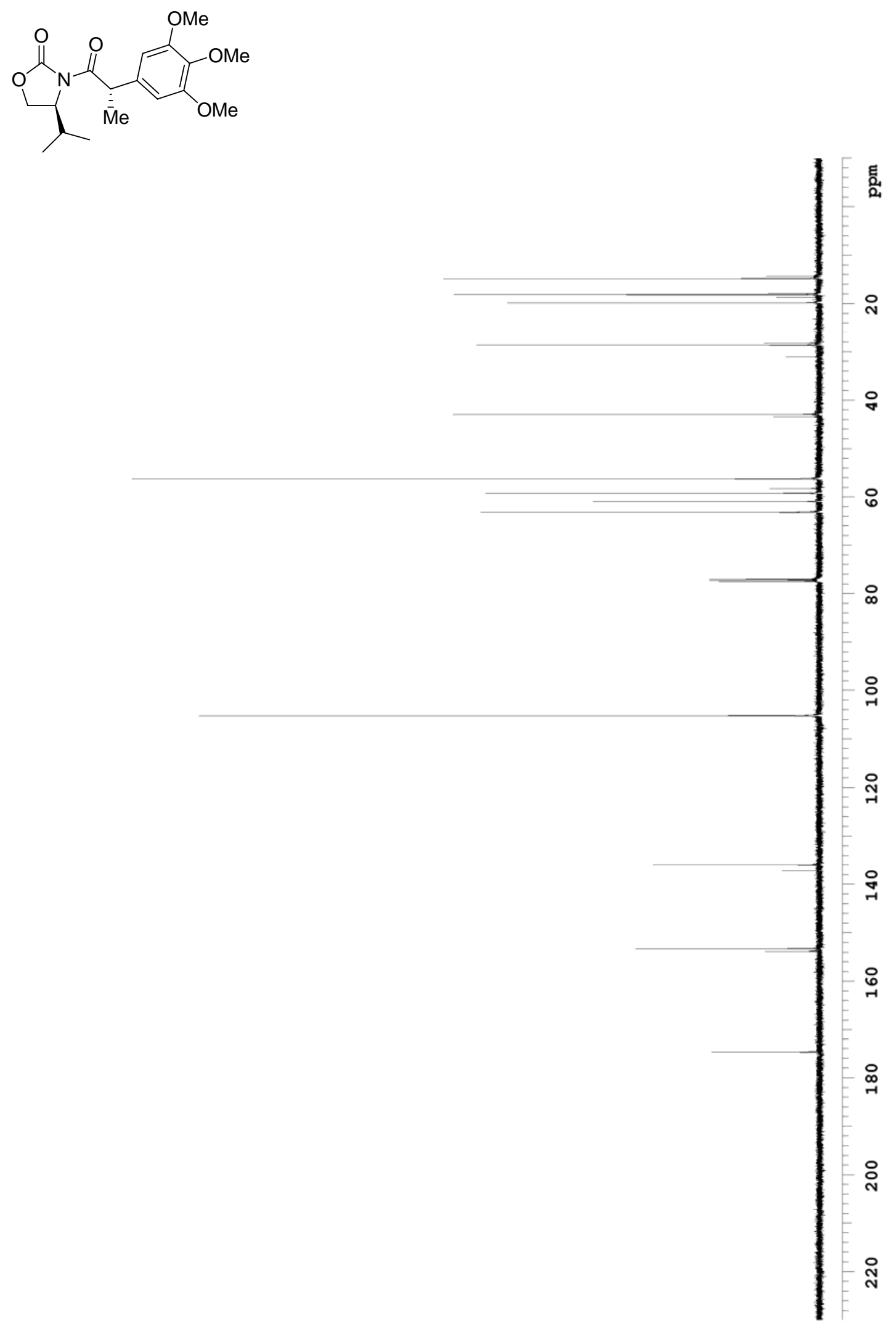

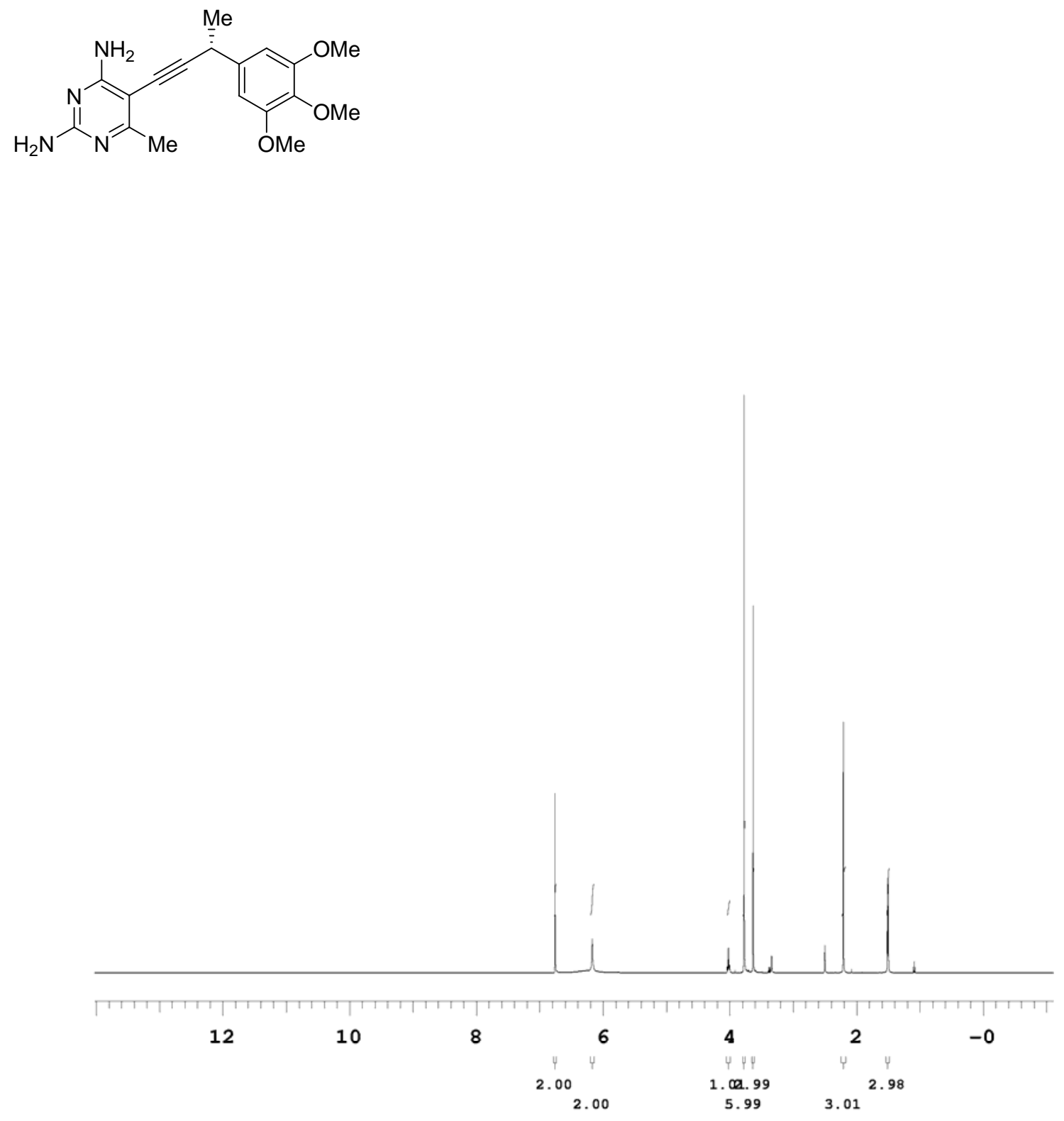

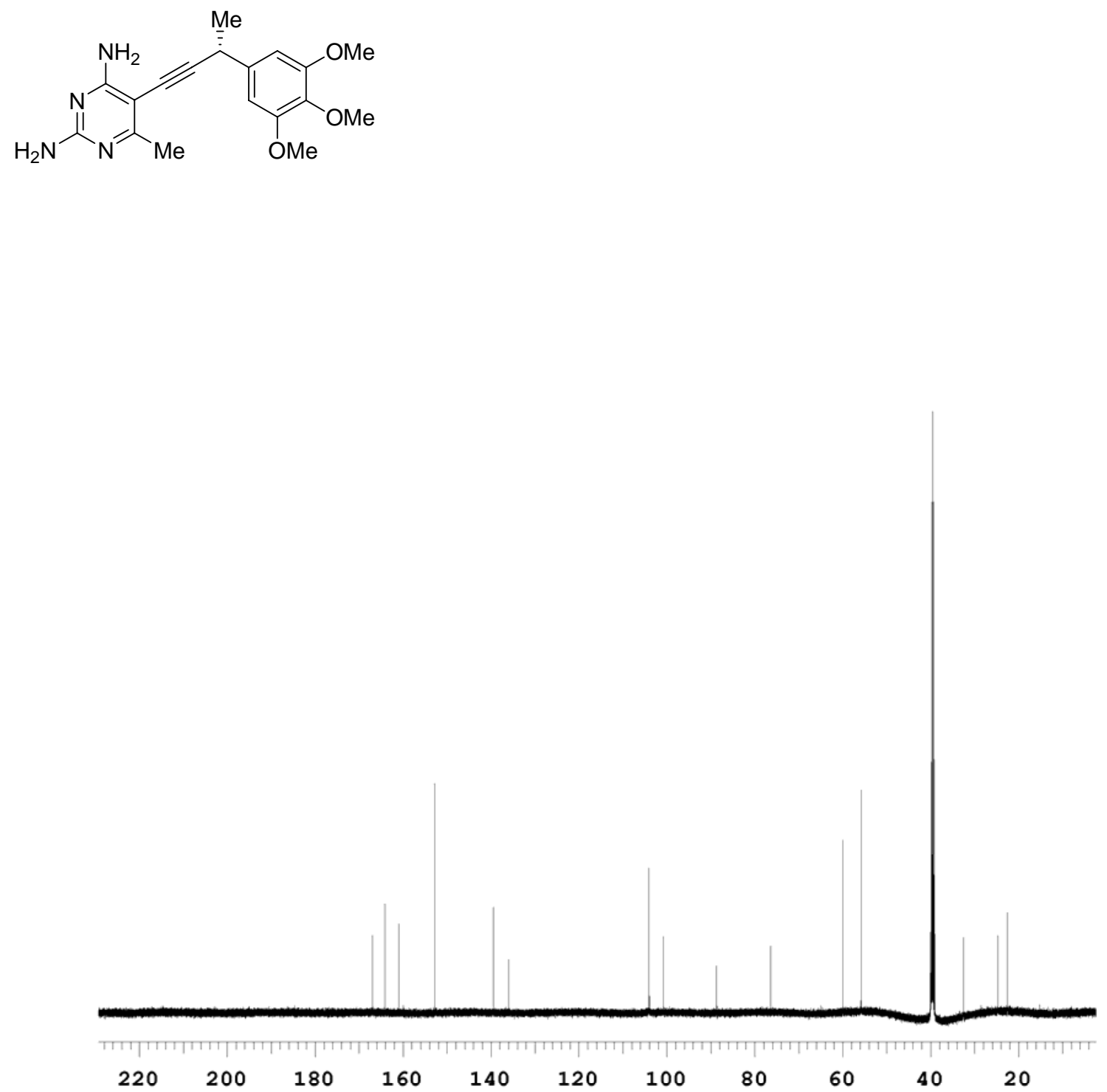
<smiles>COc1cc(C(C)C#Cc2c(C)nc(N)nc2N)cc(OC)c1OC</smiles>

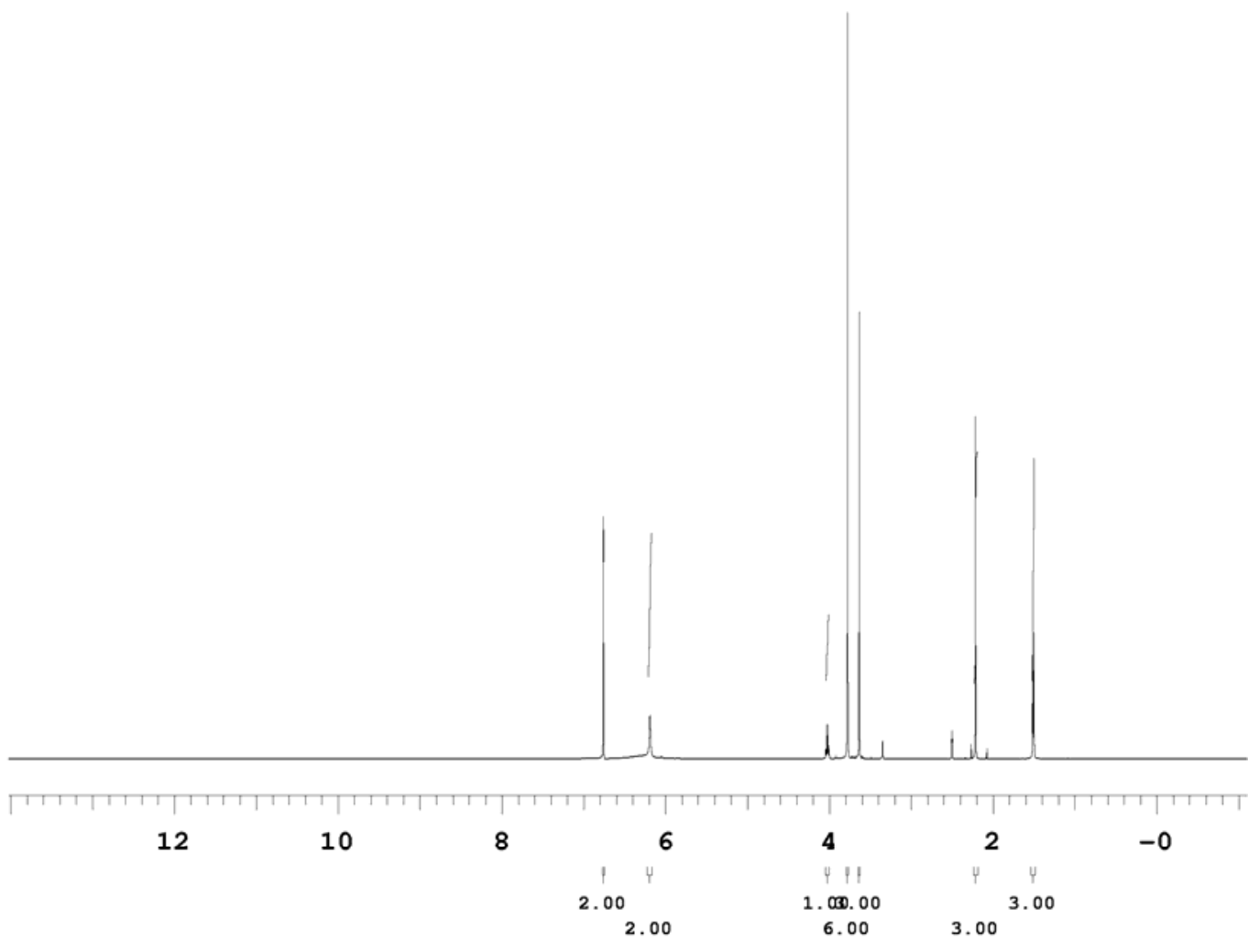


<smiles>COc1cc(C([14CH3])C#Cc2c(C)nc(N)nc2N)cc(OC)c1OC</smiles>

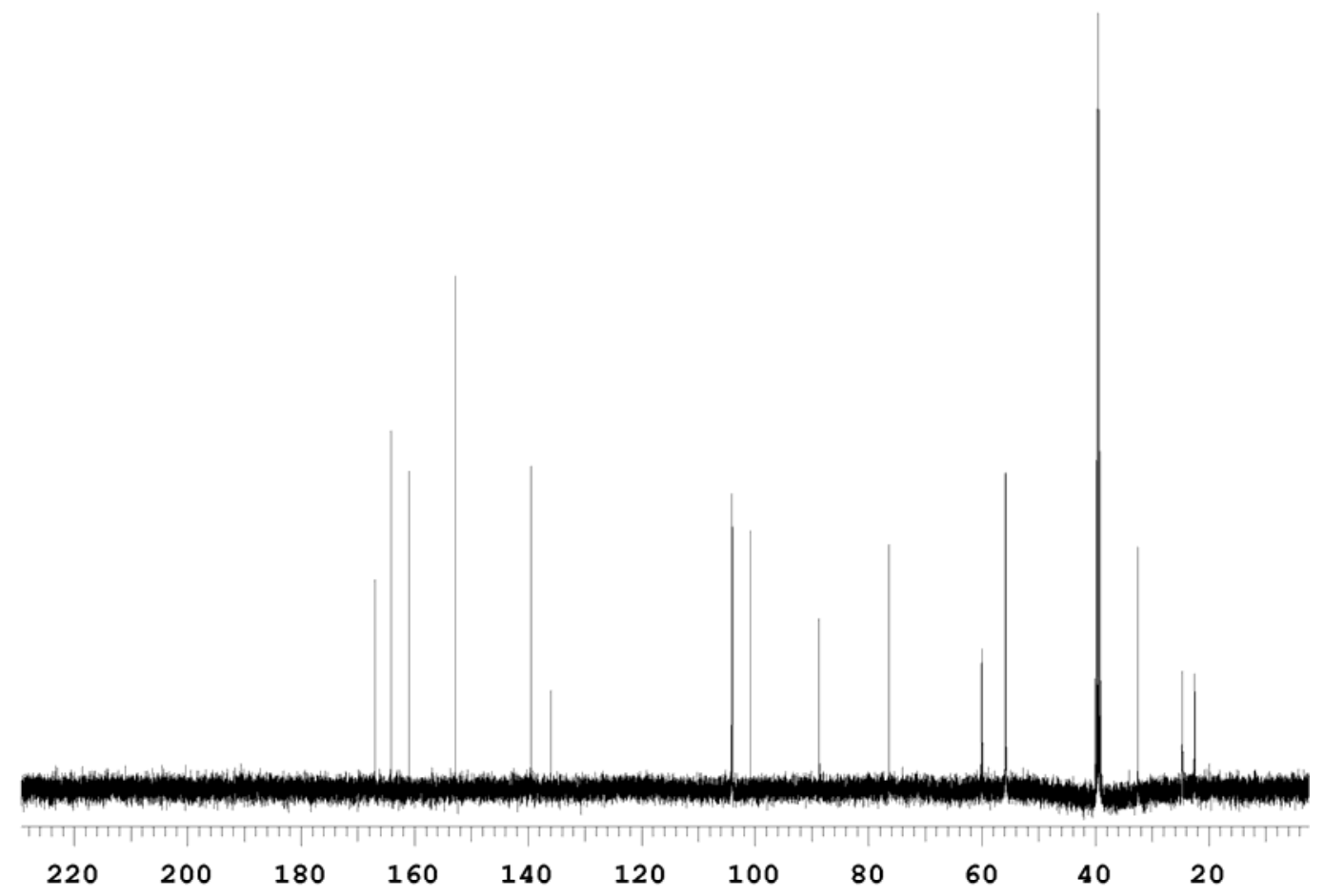

